



\title{
THE TEST-THEME IN NORTH AMERICAN MYTHOLOGY
}

\author{
BY ROBERT H. LOWIE
}

Dissertation submitted in partial fulfilment of the requirements for the degree of Doctor of Philosophy in the Faculty of Philosophy, Columbia University

\footnotetext{
REPRinted Frou The Journal of AMerican Folk-Lore
}

VoL. XXI. - APRIL-SEPT., I908. - No. LXXXI' 


Reprinted from The Journal of American Folk-Lore Vol. XXI. - APRIL-SEPT., I908. - No. LXXXi 



\title{
THE TEST-THEME IN NORTH AMERICAN MYTHOLOGY.
}

\author{
BY ROBERT H. LOWIE.
}

\section{EHRENREICH'S MYTHOLOGICAL THEORY.}

UNTIL recently two standpoints had been assumed in the theoretical discussion of American mythology. The older theory of Brinton endeavored to explain mythological similarities in different parts of the New World by the principle of the psychical unity of mankind. Uniformities of a striking character - even if found among such neighboring tribes as the Iroquois and Algonquin - were interpreted as pointing "not to a common source in history, but in psychology." $(17: 172,173 .)^{1}$ They were derived from the action of the same natural phenomena on similarly constituted minds; at the same time, the phenomena were supposed to appeal to the observer because of their association with such abstractions as light or life. In 1895 this theory was challenged on historical grounds. On the basis of North Pacific material, Boas succeeded in establishing the diffusion of complex tales and characteristic episodes over wide areas. (3:329 et seq.) The mythology of each tribe was shown to be a product of historical development, its original form having been modified by assimilation and accretions from various sources. Without denying the influence of the celestial bodies on primitive fancy, he challenged the legitimacy of any direct interpretation of myths as expressions of universal ideas before eliminating the changes conditioned by historical and geographical causes.

The recent publications of Dr. Ehrenreich (33 and 34) introduce a novel, in some respects intermediate, point of view. Unlike Brinton, Ehrenreich makes extensive use of the principle of transmission. He accepts the evidence for treating eastern Asia and northwestern America as a continuous area, and directs attention to striking similarities in the mythologies of North and South America as suggestive of an early historical connection. Also in opposition to Brinton, he rejects un-

1 The first number in parentheses refers to the title with corresponding number in the list at the end of this paper; subsequent numbers refer to pages. 
equirocally all attempts at interpreting myths as symbolical cxpressions of abstract ideas. On the other hand, Boas's objections are overruled on the plea that a reliable system of interpretation is rendered possible by comparative analysis. The primitive mind is assumed to apperceive the celestial bodies either as themselves personificd, or as the instruments of personal beings. This naire apperception leads to tales describing the phases of the sun and moon as the adventures of a human hero; or - as in the case of star-lore and portions of solar and lunar myths - to explanatory legends. The hearenly bodies furnish the principal, if not the only, subjects of primitive myth. Their motion, rise, and disappearance, their apparent flight or meeting, the terrifying phenomena of the eclipses, the growth, death, and restoration of the moon, the influence of both bodies on regetation, these are all processes which may be represented in a mythological narrative. (34: $553,55 \dot{4}$ ) The test-theme is dereloped as an explanation of the sun's sojourn in the lower world and its "visit to heaven." Eclipses and the setting of the sun are described as the swallowing of the solar hero by a monster, from whose maw he reappears without hair, that is, without rays. The opening and closing of the waters or the earth to receive the sinking sun has its counterpart in the symplegades motive, while the capture of the sun refers to the solstices. The relation of sun and moon to each other lead to many new combinations, according as they are conceived as brother and sister, husband and wife, friendly or hostile. Many distinctively human elements of folk-lore are thus traced directly to the mutual connections of the celestial twain. To these analogies of motives and phenomena must be added a long list of descriptive traits. The sun's rays are mentioned as the hero's arrows, cords, or golden hair; warts, scales, and snake-hair refer to the spots in the moon. The crescent appears as a boat, bow, or sickle; emphasis of the hero's brightness indicates the sun.

We have, then, a fairly large series of criteria by which celestial heroes may be recognized. Whether persons are explicitly identified with sun or moon thus becomes immaterial. "Dass Keri und Kame Sonnen- und Mondwesen sind," says Ehrenreich, "schliessen wir nicht daraus, dass sie so heissen, sondern dass sie sich in der mythischen Handlung wie Sonnen- und Mondhelden verhalten, deren Züge sie in seltener Vollständiglieit rereinigen." (34:575.) In fact, according to Ehrenreich, the celestial name generaily disappears at an early stage, and is superseded by an animal or human name, unless, as frequently happens, the hero is anonymous. The criteria are all-important in revealing his identity. In reply to the criticism that almost any historical figure might be identified with sun and moon by Ehrenreich's criteria, he insists that not a single, isolated trait, but the whole complex of traits appearing in the context characteristic of solar myths is required for a safe inter- 
pretation. "Es genügt eben dazu nicht cin cinz:hnes Moment, sondern nur der Nachweis cines ganzen Komplexes mythischer Züge im richtigen, für Sonnenmythen charakteristischen Zusammenhang." $(34: 576$. This principle is necessarily modilied in practice, for there are many myths in which the complete complex is lacking. These cases are $\mathrm{cx}$ plained by assuming that the missing features have dropped out, but may be detected by comparison with the versions of linguistically and culturally affiliated tribes. Thus, in his rejoinder to the euhemerist Breysig, Ehrenreich admits that the Tlingit Raren myth does not bea: the stamp of a nature-myth very clearly. To establish his point, he examines the related stories of the Tsimshian and Newettee, finds mention of the Raven's greed, burnt face, and rapid growth, his brightness, ascent to the sky, and transmutation into a pine-needle (= waning crescent), and from these characteristics infers that the Raven of the North Pacific coast is a lunar being. $(34: 568,569$.$) Similarly, though$ without detailed proof, he assumes that a great many folk-tales with indeterminate heroes, e. g. the Boy Hero tales of the Plains, were originally nature-myths, of which the celestial features have become obscured, and which have been consciously remoulded for pedagogical instruction. (34: 599.) That the reverse process has ever taken place, that human hero tales have ever been associated with sun and moon, he regards as a logical possibility, but an unprovable and unnecessary assumption. $(3+: 5+3,575$.) While not denying that the material in its present form contains elements not derived from observation of nature, he conceives these as later additions, easily separable from the primitive constituents, and supplying merely the local coloring or ritualistic setting. $\left(34: 55^{2}\right.$.) Secondary association is recognized only to this extent, that after the culture-hero, who has developed from a naturalistic substratum, becomes the national hero, ancestor, or tutelary spirit, various legends are ascribed to him in order to surround him with an additional halo. The Michabazo cycle and the innumerable Coyote tales of the prairie are cited as cases in point. (3t: 553.$)$

The fundamental proposition that mythology, so far as it is primitive, is the product of the childlike apperecption of nature, is in Ehrenreich's opinion an axiom. "Diese Thatsache ist die Grundlage aller Mifthenforschung. Jeder Versuch, andere Grundideen unterzulegen, ist bisher gescheitert und aussichtslos." $(34: 597,598$.) In order to justify an interpretative attempt from another point of view, it is necessary to winnow at the outset the hypothetical portion of the naturalistic theory from its basis of fact. It must be granted, of course, that the observation of nature has produced mythological conceptions. Where lightning is conceived as a snake, or where thunder is explained as caused by the flapping of an eagle's wings, we obviously have ideas directly derived from natural phenomena. That the lunar women wear bright garments 
(69:22), that the Sun's daughter scorches the face of a peeping intruder $(3: 40)$, or is so hot that her husband finds her company unbearable $\left(S_{7}: 55\right)$, are simple descriptions of the brightness and heat of the celestial bodies, such as may, of course, be everywere found. At times explanatory statements undoubtedly develop from these features. The Thompson River Indians not merely indicate the sister of the Man in the Moon, but explain that she leaped on his face for lack of room to sit down during a feast. (87: 91, 92.) The Arapaho account for the dark spots in the moon by the jump of Moon's offended sisterin-law, Frog-Woman. (3I: 323.) About none of these, however, is there any dispute. The moot-point is whether the narratives told in some cases of explicitly solar and lunar heroes bear an essential relation to the heavenly bodies, either themselves reflecting the succession of observed phenomena, or furnishing the explanatory elements of the celestial tale proper; or whether they are human tales which have arisen independently of observation of nature.

Now, that these consistently dereloped tales are nature-mythological in either of the ways mentioned is not a fundamental law of comparative mythology, but an hypothesis. That they are is inferred from the criteria. But the criteria are ambiguous: all are intelligible as elements of a human folk-tale. Greed and rapid growth are as natural in a human as in a celestial hero. Though the moon-spots are sometimes conceired as warts or lice, an ogre with these characteristics is not necessarily a lunar being. Magical births present no difficulty, if we remember with Wundt $(93: 330)$ that the universe of folk-lore is dominated by magic. The birth of Splinter-Foot-Girl from a splinter need not have any further psychological basis in common with other ideas of magical conception. (31: 161 .) That it has anything to do with the fertilization of the earth by the sun (34:602) would be an entirely arbitrary assumption. From the same point of view the restoration of the dead is intelligible without resorting to a corresponding phenomenon in the hearens. As for the swallowing motive, Ehrenreich admits that the natural processes which gave rise to it are not necessarily the same throughout : eclipses as well as the sunset may have inspired the idea. $(33: 53.54$.) But if a plural origin is admitted, it is difficult to understand why every instance of swallowing must go back to some celestial occurrence. In the Lte tale of Porcupine killing a fat buffalo that carries him across stream in his paunch it is difficult - in spite of the specious analog: of quills and the sun's rays to see more than a simple animal tale. $(55: 270$.) The observation of animals yields examples enough of swallowing, and the grotesquely unrealistic transformation of such observations involves nothing $\mathrm{p} 5 \mathrm{y}$ chologically improbable. 


\section{SOLAR AND LUNAR CRITERIA.}

In view of the admission that the entire series of criteria must be found in order to prove the naturalistic theory, it would not be necessary to dwell on the evident ambiguity of single traits, were it not advisable to call attention to the occasional clisregard of this caution, and to indicate, however briefly, the standing of the naturalistic theory when divorced from an interpretation of homologies. Some thirty years ago J. G. von Hahn attempted to interpret Greek and Teutonic mythology on the basis of naturalistic principles, though affirming an historical connection between them. $(45)^{1}$ His fundamental assumption was that the cycle of the seasons, owing to its importance for primitive man's foodsupply, formed the principal myth-making factor of the outside world, while the succession of day and night, meteorological conditions, and other natural phenomena, have contributed their share. The interpreter's first duty was accordingly to detect motives corresponding to these phenomena. Balder's death, from this standpoint, was taken to refer to the destruction of regetation by autumnal drought. Thor and Hercules were conquerors of winter-monsters. Eurystheus symbolized the faint new moon, and Günther's bent form, suspended from a nail, was the crescent of the moon. Without entering into a discussion of the popular-psychological basis of Hahn's sy'stem, it suffices to note that the constant error committed by him is the disregard of alternative possibilities, which is perhaps most strikingly illustrated by his conception of Günther. When Ehrenreich interprets the rolling skull of North American mythology as the setting disc of the full moon, or the head of Entangled-Man as the apparently hollow crescent (33:82), he is liable to the same criticism. The most plausible of such analogies are always subject to Von den Steinen's doubt, whether the notion is not rather the interpreter's than the myth-maker's. So far as the assumptions are concerned from which these interpretations flow, they are no less dogmas of a popular psychology than Hahn's. It is just as gratuitous to assume that the moon, on account of its numerous phases, has been a more important factor of mythology than the sun (34:554), as it is to derive mythology from the conditions of man's food-supply. There are no objective means of testing these psychological assumptions, or the more or less ingenious hypotheses built on them to explain mythological motives. Without denying the abstract possibility that any such hypotheses may be correct, the conceivability of an indefinite number of alternative explanations must lead to their repudiation. A series of criteria will not be more convincing than a single trait, if all are equivocal.

1 More recently a similar point of view has been defended by Frobenius (Das Zeitalter des Sonnengottes, Berlin, 1904, pp. 36, 47-55) and by Stucken (Astralmythen, Leipzig, I $\$ 96-1907$, pp. I89, I90). 
On the other hand, it must be granted that if the criteria are found over and over again in unrelated areas, sometimes expressly connected with - solar beings, a solar hypothesis is permissible even though the significance of the details remain doubtful. For example, it may be doubtful whether the capture of the sun in Polynesian $(89: 248 ; 42: 24-26)$ and American mythology is a description of the solstice; but, inasmuch as the proof of an historical connection between Polynesia and America is unsatisfactory, the naturalistic theory has the merit of accounting for a rather striking coincidence. This recognition of the legitimacy of the theory at the same time involves the rejection of its claims to superiority over other points of view; for, if its scientific value depends on its ability to account for homologies, other theories performing the same service stand on an equal footing. Similarities may be accounted for in other ways: by borrowing, by community of customs, by convergent evolution. In each case the theories must be tried on their merits. If, for example, so characteristic a detail as the arrow-chain appears in North and South America with fifty degrees of latitude intervening, the condition on which a sane theory of borrowing generally rests, diffusion over a continuous region, is manifestly lacking; nevertheless, the peculiarity of the motive, joined to other indications of historical contact, seems to warrant Ehrenreich's assumption of a common origin. When, however, exactly the same detail occurs in Melanesia $(2 \mathrm{I}: 375,398)$, we are naturally in doubt as to the applicability of the principle of borrowing. In the same way the specific conditions will have to decide in all cases of homology.

In a general estimate of the naturalistic theory another line of investi gation is essential. Do the heroes of solar and lunar myths as they are given to us comport themselves in accordance with Ehrenreich's scheme, or conform to some other definite type? Or does the complex of criteria rest on an arbitrary selection of those traits and actions in which the interpreter detects a resemblance to some natural phenomena? This question may be answered in a preliminary way by examining and comparing the attributes and actions of several heroes identified with the sun and the moon. If these are found to correspond to Ehrenreich's list or manifest other resemblances of a pronounced character, the essential condition for the legitimacy of the naturalistic theory, as defined above, is fulfilled. If, on the other hand, pronounced homologies are lacking, the fact that explicit solar connections in no way determine the plot will go far to justify the assumption that the solar hero whose adventures are no more circumscribed than those of a human character is simply an anthropomorphic being with a solar name.

The Sun of the Thompson River Indians is a cannibal, who hangs up his victims. His son, who is identified with a red beetle, hospitably welcomes a human hero, and sends him back to the earth with fine 
presents. The grateful youth returns to his friend, bringing a wife both for him and his father. This conciliates the Sun, who ceases to slay men.

In another tale the Sun is clescribed as a being that used to travel about naked, dressing only at night. On one occasion lie saw a boy's beautiful clothes and purchased them. ( $\delta_{7}: 52-55$, 1 го.) In Kathlamet mythology the idea that celestial beings feed on human bodies also occurs. Here the sun-bearer is an old woman, who hangs up the sun when she returns in the evening with her arrows and garments. A young man begs her for her blanket, which is reluctantly surrendered. The gift causes him to lose his senses and to kill all his friends, until the old woman appears and takes it away. $\left(6: 13^{-15}, 29.\right)$ The Kootenay speak of the Sun as a blind man, who is cured by his father-in-law, Coyote. (I2: I69.) None of these solar beings manifests a single trait mentioned by Ehrenreich, nor is there any resemblance between them. The characteristics attributed to them are either general human traits or those of folk-tale characters. Why the Sun should be conceived as a cannibal both by the Thompson River Indians and the Cherokee (66: 440 ) is not explained by the naturalistic theory. His cannibalism cannot be considered a later addition to his essentially solar traits, for these are non-existent. A solar criterion might indeed be deduced from the fact that the Cherokee explain eclipses by the swallowing of the sun by a frog. But this unmistakable nature-myth proper is not embodicd in a tale. (66:257.) The tales connected with the Sun - and these only are the subject of this discussion - relate that the Sun is a transformed girl, beloved by her brother (a story probably derived from other tribes); ${ }^{1}$ and the circumstances relating to her daughter's death. The Sun used to hate people because they could not look straight into her face, and killed them. Rattlesnake and the Uktena monster agreed to bite her as she left her home in the morning. By mistake Rattlesnake attacked and killed Sun's daughter instead. To appease the Sun's anger, the dead girl is recovered from ghost-land, but turns into a red bird on the way back. Sun weeps, threatening to cause a deluge, until the Indians finally succeed in diverting her mind. (66:252-254.) The tales present no solar criterion: the solar name is again joined to an indifferent plot.

In the Maidu myth the swallowing motive is incorporated in the story. Sun dwells in an insurmountable house of ice, to which she retreats after killing people. She kidnaps Frog's children and is pursued by the angry mother, who swallows her. Sun bursts her enemy open, and transiorms her into a frog. She tries travelling by day, but is annoyed by the attentions of the Pleiades, and exchanges functions with her brother Moon. In another story brother and sister do not rise at first, until biting fleas make them ascend to their present habitation.

1 This story will be discussed later. 
(24: $76-78$.) I have indicated above that the swallowing motive is ambiguous. In the Maidu myth it does not appear in "the characteristic solar combination." There is consequently no more reason for emphasizing this event than that of the abduction of Frog's children. Unless reliance is placed on isolated traits, the Sun of this tale cannot be taken as a solar heroine. In an Arapaho tale the Sun is a handsome young man, who assumes the shape of a dog to marry a girl. In another legend - he argues with his brother Moon about the merits of human women, stating his preference for water-animals; he marries a frog-woman. (3I:206, 32I.) The Sun of the Shoshone does not rise in the beginning, and kills people by his heat until Rabbit shoots him with his magical arrow (fire-drill). (70:52.) Magical conception, tests, the symplegades, the capture of the hero in a trap, are not found in a single one of the instances mentioned.

Turning to tales in which the Sun is caught, we find indeed this conceivably solar trait, but in isolation. Among the Ponca it is not the captured Sun that is swallowed, kills Winter, etc., but his captor Rabbit. (32: I4.) In the Menomini (50: $18 \mathrm{I})$ and Ojibwa (78: 239) versions the solar cycle is also lacking, and the captor is an inceterminate boy. While, therefore, it cannot be refuted that these tales are nature-myths which have been developed into a simple narrative, the complex is again lacking, and the Sun of these tales is not a solar hero in any useful sense of the term. It is interesting to note incidentally that in the Northwestern plateau area it is the Wind, and not the Sun, that is snared. $(76$; $87: 87 ; 3^{6}: 42$.)

The argument is strengthened when we compare a number of lunar myths. The Eskimo Man in the Moon assists poor boys, turning the tables on their abusers. He protects a woman from maltreatment by her husband and raises her to the sky. His visitors are obliged to keep a straight face while the sky-woman endeavors to make them laugh. (I: $598 ; 5:$ I 86 , I 98.) The Moon of the Thompson River Indians is a grcat smoker, the clouds representing the smoke from his pipe. He is holding his pipe in his hand, and wears a basket for a hat. (87:9I.) The moon-bearer of the Navaho is a very old man, who lives in a row of stone houses. He does not seem to appear in any tale. (6I : 8o, 86.) The Athapascans speak of a lunar boy who saves his people from starvation. Owing to their neglect to set aside part of the food for him, he leaves for the moon, where he is seen to-day. $(69: 66,194,395$. This Moon-Boy is not a lunar being as defined by Ehrenreich. A descriptive trait, the spots interpreted in this case as the boy's dog and vessel, is not indeed lacking; but the characteristic incidents, rapid growth, death and resuscitation, or swallowing, are lacking. In one version we are even told emphatically that the lunar boy did not grow at all: "L'enfant ne grandissait pas. Quelques saisons s'écoulèrent ainsi, 
l'enfant demeurait de taille exigue." $(69: 395,396$.) The lunar women who also figure in Athapascan folk-lore are ordinarily invisible. One of them deceives her human husband by consorting with a serpent. The husband leaves both, but is followed by the second wife, with whom he becomes the ancestor of the Loucheux. $(69: 20,28$.) In another tale the women appear as Sein plein de beleltes and Sein plein de souris. They cause their lover to be swallowed by the earth. He is rescued and attacks the Mouse-Woman, liberating the mice, moles, and vipers hidden in her bosom. Being immortal, she cannot be killed. $(69: 356$.) In a Tlatlasikoala tale the Moon descends to the earth and prepares a dancing-hat and a rattle. He transforms gulls into human beings, who act as his slaves. Suddenly a man appears from the sea and offers him a large stone. Moon challenges Waqaos, who also owns an immense rock, to a weight-lifting match. Moon is defeated; thenceforth the men live together and catch salmon. In another story Moon abducts girls fetching water and raises them to the sky. (3: I9I.) In a Bella Coola myth Moon seduces a woman and is decapitated by her enraged husband. Sun, Moon's father, descends to the earth, recognizes his son's head, and causes a conflagration in which all but his son's mistress perish. That Moon is restored to life is not stated. $(3: 247$.) Thus, in each case cited, solar and lunar characteristiçs are found partly or, more frequently, entirely missing. The beings named Sun and Moon have nothing in common with one another but their names. Their attributes and actions, as empirically given, regardless of $\grave{a}$ priori speculations, do not conform to a solar or lunar norm. ${ }^{1}$ The complex is over and over again found to be lacking; it must therefore be assumed to have been constructed by an arbitrary selection of features to which in reality there is often nothing to correspond in the available myths dealing with sun and moon. The actions of solar and lunar heroes are in reality coterminous with those of human beings.

\section{AN ALTERNATIVE THEORY.}

The way is thus cleared for another point of view. The heroes of mythological narratives may be assumed to be human characters. In the absence of positive testimony, they cannot indeed be construed as historical figures. The alternative here proposed is not naturalism or euhemerism, but naturalism or fiction. Where sun and moon appear as actors in a story, there has been a secondary coalescence of their naturemythological personification with an independently developed tale, and the mythological concepts embodied in such tales are not determinant factors in the development of the plot. Whether this theory

1 "Unsere Aufgabe ist, die psychologischen Gesetze aus dem historisch gegebenen Mythenmaterial abzuleiten, nicht aber dieses nach aprioristischen Konstruktionen umzudeuten oder diesen anzupassen." (34:578.) 
answers the facts better than its alternative is best decided by limiting our consideration to a definite group of facts. The test-theme, which Ehrenreich considers the most interesting episode of solar myths, furnishes a farorable subject for this inquiry. On the naturalistic theory, the test-theme accounts for the sun's sojourn underground and its visit to the sky. While the single incidents are not necessarily related to natural phenomena, the symplegades form a substitute for the swallowing episode.

The rival theory endearors to prove that the tested heroes are human characters. The trial-theme represents human conditions, and its universal distribution is thus explained without recourse to celestial phenomena. Special homologies may be accounted for either in the same way or by borrowing and convergence. The naturalistic position is directly attacked in two ways. In the first place, the attempt is made to prove that, granting the establishment of distinctively celestial criteria, the complex of criteria is lacking or deficient in trial-myths. Even where a union of several criteria occurs, the doubt may sometimes be raised whether this union does not result from a later amalgamation. But, inasmuch as some of the heroes are ostensibly solar beings, the absence of common criteria in their myths strengthens the contention - already made in a preliminary way - that the criteria assumed by the naturalistic school have been arbitrarily selected from the totality of characteristics actually attributed to sun-beings. The conclusion, however, that no celestial characteristics exist, will result most clearly from the proof that secondary association of celestial beings with human folk-tales has repeatedly taken place; for thus the number of "characteristics," as derived without selection, becomes indefinite, and the hard-and-fast line between solar and human characters disappears.

The material referred to in the following discussion has been summarized at the end of this paper (pp. I $3+$ et seq.). Following Ehrenreich, I have classed under the head of test-tales not merely stories of formal trials, but a number of typical hero-tales containing the same or related motives. The derice, so successfully used by Ehrenreich, of denoting episodes by brief catch-words, has been adopted, so far as possible, to avoid needless repetition.

IV. HUMAN FEATLRES OF THE TEST-THEIE; THE SYMPLEGADES MOTIVE.

The first point worth investigating in the consideration of our North American material is the extent to which the test-theme is found in connection with visits to the sky or underworld, of which it furnishes, on the naturalistic theory, the explanatory motives. $(34: 555$.) Confining our attention to the test-tales proper, the descent to the lower regions plays an important part exclusively in the Quiché myth. In the Chinook 
(2:34) and Quinault (35: i I 4 ) legends, the journey to the supernatural people forms merely one of the trial-incikents; besides, the travellers in these tales are particularly lacking in celestial traits. Sisemo is an entirely indeterminate human being; and the nameless Chinook hero is merely the youngest of five biothers, who has made his escape from the pursuing Giutton. The ascent to the sky occurs more frequently; nevertheless, a majority of the tales lack both of these features. In the Wintun-Yana myths the testers are indecd identified with sun and moon, but their heavenly abode is assigned to them only as a result of the pole-bending contest with the hero. The trials of the Prairic stories have a pronouncedly human setting, and the same applies to most of the Eastern tales. In one of the Micmac stories the hero is carried up to another world by his big bird; but this region is not identified with the sky, and all the actors are human personages. The visit to the sky is thus seen to be a trait only of the Northwestern and the Pueblo myths. The question arises, whether this feature was not originally extant and has subsequently dropped oul. To a limited extent this theory is not improbable. On the Pacific coast, in particular, where the union of the two themes is characteristic of the complete Nutka, Comox, and Fraser River versions, this is a likely hypothesis. We find one Newettee version with the ascent motive, and one without it $\left(3: 170,1_{9} 8\right)$; the motive is lacking in the related Nimkish tale (3: 135) and its Kwakiutl parallel. (14:96.) In these special instances secondary dissociation may have taken place. Whether the union of the two themes may not itself be a secondary development will be considered presently. In this connection the important point is that the occurrence of the trial-theme without a trip to the heavens is only to a very limited extent accounted for by the assumption of a later dissociation. The highly characteristic recognitiontests of the Buffalo-Woman myth, the desertion of the Algonquin hero on the strange island, the contests of the Chinook and Quinault travellers with their hosts, are features not found in any of the "sky" stories; and the supposition that a visit to the upper world was ever joined with these narratives is gratuitous. We are thus obliged to acknowledge the existence of a considerable number of test-tales to which the naturalistic interpretation cannot apply. The trial-theme, so far as we are able to judge, has developed independently in these cases as an element of human folk-tales; and the only question is whether the tales of trials in other worlds have arisen not as human tales, but as explanations of natural processes.

On the other hand, we find a fairly persistent human fcature in our material, which the naturalistic hypothesis ignores. In a majority of cases it is the suitor or husband that is tested by his wife's relatives, or, more rarely, by the girl herself. This motive, which occurs far more frequently than the visit to heaven, cannot be disregarded by a theory 
which professes to account for similarities. As an element of a human tale it requires no explanation; but it is evidently not one of those "apparently human traits" which lend themselves to a naturalistic interpretation. (34:552.) This was fully recognized by Andrew Lang. (57:88, 97, 99-10r.) Lang, however, treats the tale of the youth's wooing, the girl's assistance, the tasks set by her ogre father, and the magic flight, as elements of one tale. Accordingly, he assumes that where, as in the Algonquin tale, the elements of the magical flight and the girl's counsel are lacking, these features were once extant, and accounts for the extraordinary distribution of the complete tale by transmission. So far as the magical flight is concerned, Lang's conclusions have been generally accepted because of the very peculiar character of this episode and the special analogies found in the versions of a continuous, though immense area. The North American trial-tales, however, are not very frequently joined to the magical flight, and such persistent details as the ever-recurring magical comb are lacking. The Algonquin story referred to has not a single motive in common with the Ponca or Crow buffalo myth. The tales of the Northwest are radically different in type from those of the Micmac or the Cree. The general antagonism between host and son-in-law is manifestly insufficient as an indication of historical connection. The distribution of the idea must be taken as the reflection of a widespread social phenomenon, just as the imposition of trials by the jealous uncle of the Haida and Tlingit results undoubtedly from a more definitely localized custom, the familiarity of a youth with his maternal uncle's wife. (86: I 40, I 42, 273, 277, 280, footnote I.)

Turning to the problem whether the tests are ever a characteristic portion of the solar narrative, we may first consider those tests which are supposed to bear an immediate relation to natural phenomena. Ehrenreich has united these under the caption "Symplegades Motive." "Das Symplegadenmotiv ist wohl universell verbreitet und gehört gewissermassen zum eisernen Bestand aller Sonnenmythen." (33:50.) It is believed to represent the sinking of the sun into the opening and closing earth or sea, and thus replaces the swallowing monster. (34:605.) Its variants in North America are innumerable; the most important being the crushing entrance to hearen, snapping doors, falling or striking trees, the wedge-test, and the ragina dentata. Now, this conception of a number of ideas as fundamentally related is manifestly at the basis of the universality of the symplegades motive, and the question is whether the classification is warranted: It may be based on either one of two considerations, or on both of them: the intrinsic similarity of the "variants," or their occurrence in the same solar context. So far as the first of these reasons is concerned, its adequacy is subject to doubt. When we hear of the moving entrance to the sky, we are indeed dealing with a nature-myth, and the only doubt that can remain is whether 
this cosmic notion is related to the sun's travels. That, however, the snapping pine-tree of the Californian myth, or the snapping gate of a Newettee chieftainess, originated from the same observation, is by no means certain. The wedge-test and the vagina dentata present altogether peculiar features with the flimsiest of resemblances to each other and the remaining variants. It may be justifiable to denote all cases of the closing of an aperture by a common catch-word, but a psychological relationship is not demonstrated by the arbitrary selection of a superficial resemblance as the basis of the classification. Our doubts are confirmed when, treating each of the symplegades variants as a distinct motive, we consider the context in which they occur. In a Yuchi myth four men who visit their dead wives are arrested on their way by a huge cloud which moves up and down; three of the travellers pass in safety, the last is crushed. (82.) Equally indifferent personages are connected with the snapping sky-hole by the Ojibwa and Cherokee. (78:286;66: 256.) In a Hare Indian tale a magician arrives before the snapping entrance to the spirit world; by uprooting the tree that bars ingress he succeeds in reaching the interior of the cave. (69: 131.) Such instances seem to indicate a real nature-mythological conception, but one that is entirely independent of a solar narrative, and accordingly appears in the celestial trips of indeterminate heroes as well as of the Tsimshian Raven. (3:274.) To the question whether the flight to heaven is essentially a solar characteristic and originally appeared as such, we shall have to return presently. The distribution of the snapping door, granting that the idea is strictly homologous with that of the crushing sky-hole, merely enforces the conclusion here reached. In a Chukchee tradition a travelling youth arrives at the house of a rich maiden he desires to marry. He is obliged to enter by the snapping gate, but leaps in so swiftly that only his coat is caught. (15:666.) A similar adventure is related by the Eskimo of Kiviuq. (5:184.) The Heiltsuk ascribe a snapping gate to Thunder-bird's house; a similar dwelling is constructed by a Newettee chieftainess, and received by $\bar{O}^{\prime}$ maxtalatle as a gift from his father-in-law. $(3: 228,186,166$. $)$ In a Bella Coola legend five brothers escape from the pursuing ogre by leaping through an eagle's snapping beak into their savior's hut. (3:253.) Komokoa's submarine mansion is entered by a sea-monster's snapping mouth. (3:239.) In a Comox tale the old man who wishes to keep fire for himself builds a house with a rapidly-shutting door to keep off strangers; Deer manages to jump in and steals the fire. (3:8I.) A Shoshone ogre dwells in an automatically-closing cave from which two brothers rescue their sister. (6o.) In short, the snapping gate is neither an element of the visit to heaven, nor is it necessarily joined to tales of conceivably celestial beings. It is a perfectly free element of folk-lore, appearing in various combinations. Its distribution is perfectly intelligible on the theory of borrowing. 
The wedge-test occurs on the western coast of North America and in Japan. As Ehrenreich himself assumes an historical connection between the trial-tales of these regions, his naturalistic conception of the motive rests exclusirely on its analogy to the generalized symplegades idea. He forgets his own caution here, that motires cannot be regarded as psychologically related unless they are not merely analogous, but identical. (33: 7 I. $)$

The table of the North Pacific trial and transformer myths, given on p. I35, indicates that the wedge-test is found repeatedly without the flight to the sky. If the motive has been imported from Asia, it is significant that this feature is lacking both in the Japanese and the two Alaskan tales, and appears precisely where the ascent to the sky is a particularly prominent incident, so that a secondary association is highly probable. The falling trees probably represent a modification of the wedge-test in a Kathlamet version, where Mink is sent to fetch wood and the tester attempts to kill him with thick trees. Here at least some of the other incidents are closely parallel to the trpical trials of the coast region, so that substitution may have taken place. But the striking tobacco-trees that appear in the transformer cycles of the Chilcotin and Shuswap may have had an entirely different origin, as may also be supposed for the bending trees of the Crow twin-my th. At all events, as a naturalistic theory has been rejccted, the homology of the falling trees to the rariant most closely related to it is immaterial. There remains the vagina dentata, "the most interesting variant of the symplegades motive." In regard to Ehrenreich's interpretation of this motive, it seems to me that eren those not on principle opposed to an ultimate explanation of mythological motives must find the connection with heavenly events far-fetched. An explanation from biological considerations, taking into account the widespread blood-superstitions of primitive tribes, would possess more à priori probability. Waiving these hypothetical considerations, we find that the distribution of the motive does not require a naturalistic theory, for though widely disseminated, from eastern Europe ${ }^{1}$ to the Teton Dakota, this extremely characteristic detail may be traced with few gaps from one extremity to the other. So far as the context is concerned, a connection with the Sun's or SkyChief's daughter is established solely on the basis of the Comox and Kwakiutl versions. ${ }^{2}$ Eren on the Northwest coast the incident appears dissociated from the trip to heaven, occurring sereral times as an episode of the transformer's travels $(3: 24: 4: 76: 36: 13)$, in which case the wanderer is said to cause the loss of tecth in later generations. In the same way Coyote makes procreation possible in the origin myth of the Shoshone. The Maidu Thunderer is amenable to Ehrenreich's

1 Bogoras traces the idea to Finland.

2 It occurs, howerr. in an unnublished Tsimshian version of the Astiwall myth. 


\section{The Test-Theme in North American Mythology.}

theory, but in the Arapaho $(3 \mathrm{I}: 260)$ story the actors are entirely indeterminate. Child-of-a-Dog, the Wichita hero, in the course of his travels, falls in with two toothed women, who have, as far as we know, no relations to either sun or sky. (27: I +4.$)$ In the Skidi version the woman is indeed descended from the animal deities or the EreningStar; but the plot develops on the earth, and the hero is the characteristic Poor Boy of the Plains, assisted by Morning-Star. (28:35;30:4I.) In a Teton tale the woman on the strange island tries to kill the deserted boy, not, as in the more familiar version of Riggs, by smothering him with blankets, but with her tectì. (92: 198.) In the Asiatic and European versions the case is clearer still. In a Chukchee variant the man destroys the teeth and marries the girl; in the Yukaghir tale he enslaves her. In the story from northern Russia a girl marries a man against her inclinations, and terrifies her husband by inserting pike's tecth in to her vagina. ( $5: 667,668$.) A very similar tale was recorded by Dr. Krauss among the South Slavonians. (53: 250, 253.) In the Ainu story a distant island is peopled with women whose teeth sprout in spring, but fall off in the autumn. (19:38.) The ragina dentata thus occurs so frequently in purely human tales, that its occasional occurrence in narratives of conceivably celestial beings must be considered accidental and insignificant. Summing up, my conclusion as to the "symplegades motive" is that this caption unites a number of radically distinct ideas, so that the universality of the motive, resting, as it does, on the homology of these features, is illusory; that the distribution of each of the distinct motives is intelligible without a naturalistic hypothesis; that the combinations in which the "variants" appear suggest human rather than celestial characters. The motives are neither universal, nor are they characteristic of solar myths.

\section{THE ASCENT TO THE SKy.}

The problem still confronts us whether the test-theme of the Northwest coast, the Quiché, and the I'ueblo, has developed independently of the human test-stories, or whether the association here found between a visit to other worlds and trials is secondary. This question is, of course, of theoretical importance only if the ascent to the sky is itself a solar criterion. This assumption may be challenged so far as the North Pacific region is conccrned, for the ascent occurs in all conceivable combinations. A Tsimshian hero travels up on the arrowchain, causes the sun to stand still, is hospitably received by the chief, purified, and dismissed with instructions to his people. In another Tsimshian story three hunters are magically raised to the stars while asleep. Two of them cndeavor to climb back, but perish. The youngest, counselled by the Sun's daughter, prays and reaches the earth unhurt. (3:278, 290.) In a Haida story a rejected lover ascends to the 
sky by an arrow-chain, is beautified by Moon, and on his return so fascinates the woman once courted by him that she dies when repelled by him. $(86: 354$.$) In a tale from the same tribe, a man pursuing his$ bird wife (swan-maid) climbs up a pole into the sky, and meets the woman, with whom he lives for some time. Becoming homesick, he is taken down, but dropped by Raven, and turns into a gull. (86:264-267.) In a Comox tale Pitch's sons scale the ladder to avenge their father's death, slay the Sun, and themselves assume the functions of sun and moon. $(3: 64,65$.) For similar reasons two Tillamook boys ascend to the sky, kill the chicf's wives, and put on their dress. Posing as the two women, they slay the chief, revive and marry his wives, and resuscitate their father. (8: 136 .) In a Thompson Indian myth the birds climb up to make war on the sky-inhabitants. (3:17.) The Nimkish Goose-Boy escapes from frogs by flying to Kantsoump, whose daughter he peaceably takes to wife. (3: I 47.) In a Quinault tale, Raven's daughter and her friend are taken to the sky by a star. One of the women escapes, but fails to get back to the earth. Her people ascend by the arrow-ladder to rescue her companion, assail the celestial people, but are forced to retreat. (35: 107.) To wage war on the Southwest Winds, some Kathlamet heroes tilt the sky until it reaches the earth, and leap up. (6:67.) A Tsetsaut is taken to the sky during the night. The chief puts him into a sweat-house, then allows him to marry his daughter and return to earth on the rainbow bridge. $(9: 267$.) The ascent to the sky is thus seen to be a very common and a very free element of Northwestern folk-lore. In a less specialized form it is found all over the continent, often, as in the Yuchi, Hare Indian, and Cherokee myths, referred to in connection with human wanderers. We are thus justified in assuming that the flight to the sky in our Pacific myths, instead of being a characteristic of the sun, has entered the narratives of allegedly celestial beings simply because of the popularity of the motive in this region. This implies, of course, that even when joined to the flight to the sky, the test-theme is not the explanatory feature of a solar nature-myth.

\section{CELESTIAL AND HUMAN TEST-TALES.}

If this conclusion is rejected on the (unprovable) hypothesis that the ascent was primarily joined with the other solar criteria, the problem may be approached from a different point of view. Are there any distinctive traits in the celestial trial-tales that differentiate them from those of earthly plots? We have seen that this proposition does not hold for the symplegades motives, but the remaining trial-incidents require consideration. On consulting the table on p. I 35 we find that all the characteristic details which are found among the Nutka and Comox occur likewise among the Quinault, Thompson River Indians, and Chinook. The tales of these tribes cannot be regarded simply as dis- 
figured cditions of the more northern versions; for rather characteristic trial-episodes, such as the trip to the supernatural people and the attack of the tester by captured animals, are found well developed in them. 'The sweat-lodge trial occurs in the Ponca buffalo tale, where the human hero is obliged to compete with his mother-in-law, in the visits of the Chinook and Quinault travellers to strange villages, as well as in the Thompson River version. In the familiar Bear and Deer story the incident plays a prominent part (24:79), and it recurs with a human hero in the Yukaghir tradition. Tcatcewiqso, in a Tillamook story, is killed in a sweat-lodge by his father-in-law, and transformed into flint. (8: I 36.) The fire-ordeal is, if anything, still more widely distributed, occurring with particular frequency in the numerous witch stories of the prairies. The only motive which, as far as I know, does not appear in human tales (that is, tales in which neither the ascent to the sky nor the descent to the underworld occurs), is the spine-seat, but this single peculiarity cannot be considered significant. Finding a considerable number of test-stories which cannot have been derived from the celestial tales, and finding practically every trait of the latter duplicated in the former, it is plausible to assume that the celestial setting is a secondary addition. At all events, the trip to the sky is not to be considered indicative of a non-human tale. This supposition is not refuted by the assumption that the myths dealing with Susanowo and his tested son-in-law form the prototype of the North American myths of the visit to the sky and the trials connected with it (33: 8I); for, in the first place, a descent to the underworld is not exactly the same as an ascent to the sky, and this ascent to the sky Ehrenreich in his later paper regards as a part of the oldest stratum of North American tradition. (34: 569.) If, therefore, the trial-incidents have been adopted from Japanese sources, the union of trials with a visit to the sky is secondary, - a conclusion in accord with my argument. But the grounds for assuming either an historical connection between the Japanese and the American myths, or a nature-mythological context for the Japanese tests, are insufficient. That both the Quiche twins and the Japanese hero are cast into chambers of horrors proves nothing, first, on account of the immense distance between these regions; secondly, because the rescmblance is an exceedingly general one. The son-inlaw of Susanowo is cast into the House of Snakes and the House of Centipedes and Wasps; Hunahpu and Xbalanque are sent to the House of Darkness, the House of Lancers, of Cold, of Tigers, of Fire, and of Bats. There is nothing characteristic about the "Glutstein" of Ehrenreich, and as a matter of fact the connections in which it appears differ in the Japanese, Comox, and Quiché traditions. In the Japanese tale the eighty jealous deities pretend to drive a red boar towards the hero, but instead roll a glowing rock down the hill. In the Comox myth Aielen's sons are obliged to swallow the heated stones; in the Central

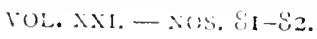


American cycle the hot stone forms the settee, and thus is analogous to the spine-seat, as Ehrenreich elsewhere recognizes. (33: 50.) The only characteristic special analogy of the Kojiki and American test-theme is the wedge-test. This might be taken as suggestive of historical connection, but, standing by itself, it is not conclusive. Besides, this feature occurs precisely not in the trip to Susanowo, but among the carthly adventures of Oho-na-muji. On the other hand, the trials of the hero in the underworld may have been derived from the Mongolian story of Geser, who is thrown successively into a snake-pit, the den of ants, lice, wasps, and wild beasts, by order of the Chinese sorereign. At all erents, the resemblance here indicated is far more striking than that between the trials of the Kojiki and those of the Popol Vuh, and transmission is more probable among eastern Asiatic peoples than between Japan and Central America. The lousing incident of the Kojiki implies nothing as to the lunar character of Susanowo, for it occurs frequently in other connections among the Amur tribes, and is simply the reflection of a social custom. "Picking lice from each other's heads is a sign of mutual friendship or love. It takes place, therefore, between spouses or between related women." (59:337.) It is thus elear that even if Japanese folklore has influenced the American tales of suitors' tests, the naturemythological conception of the Japanese myth is arbitrary, and ignores weighty considerations in favor of borrowing and an interpretation from human conditions.

\section{SOLAR CONTEXT OF TEST-TALES.}

But in order to test the naturalistic theory from a wider point of view, irrespective of Ehrenreich's special hypotheses, it is desirable to consider whether the tested heroes of this area, regardless of visits to the sky or underworld, can be safely identified with the heavenly bodies. The tried hero of the Northwest may be a human being (Chinook, Quinault, Fraser River), sometimes of magical birth (Nutka: Anthtine = Nasal Mucus), the Raven or Raven's father (Tsimshian, Newettee, Tlingit), Salmon-Boy (Bella Coola, Chilcotin), the Transformer (Newettee, Kwakiutl, Thompson River), Mink (Kathlamet), the Sun's son (Comox), the son of the man from the sea (Nimkish), or a human boy hero (Nass River, Tsimshian). When we find that in one Kwakiutl version the hero is Gyii (3: 135$)$, while in two other versions of closely related tribes the same adventures are told of Gyii's foe, Kanigyilak, (3: 198; $14: 96$ ), the transformer, we obviously cannot be sure whether the trial-motive belongs to the one or the other, and cannot safely treat it as a solar criterion of either character. Ehrenreich recognizes, of course, that secondary transference of plot from one character to another, and secondary combinations, have taken place. His error consists in refusing to admit that this concession eliminates a naturalistic 
theory. He recognizes the difficulty of interpreting certain myths owing to the fact that the relations to the natural phenomena are "durch andere Vorstellungsgruppen iiberwuclert;" still the uniform recurrence of the same nature-mythological motives in the same combination is considered conclusive. (3+: 596.) I have already indicated that, in spite of the ambiguous character of these motives, this point of view is one of the relatively legitimate standpoints taken to account for similarities of mythology. When, however, Ehrenreich grants that the introduction to the Tsimshian Raven cycle may be a southern importation from Vancouver Island, and at the same time contends that the Raven myth as a whole has been introduced from Asia, this is not "für unser Thema . . nebensächlich" $(34: 569)$, but a point of fundamental importance. If certain lunar traits have originated in Koryak mythology, while the visit to heaven is an indigenous element, the complex of celestial criteria has developed secondarily, and allows no conclusion as to the celestial nature of the hero. Similarly, if Mink's swallowing by a whale is an episode borrowed from the Raven myth $(3: 338,339)$, his solar traits are reduced to descent from a being named Sun and to the ascent to the sky, the union of which (disregarding their equivocal character) is very far from representing the imposing array of solar criteria enumerated by the naturalistic school. When we find, in addition, that the predominant characteristic of Mink is his amorousness, a human trait $\left(3: 33^{8}\right)$, the assumption that Mink is a solar being appears entirely unjustified by the facts. $(34: 568$.) In examining one by one the heroes of the test-stories, the solar context is found noticeably lacking in the majority of instances. This is of course particularly clear in the case of the ostensibly human heroes. The magical birth of Anthtine from his mother's tears and mucus, being found in human connections, serves rather to show that the magical birth of a hero is a simple element of folk-lore (cf. Splinter-Foot-Girl, Blood-Clot) than to support the naturalistic conception. (3: I I 7.) Raven, so far as I know, appears in the part of the tested only in the Tlingit version of Krause, and there the visit to the sky is not joined with the trials. The closest parallel to the Tlingit tale, that of the Kadiak Eskimo, relates the same adventures of a human hero. In those Tsimshian and Newettee versions in which the part is assumed by Raven's father, the test-theme is quite rudimentary, so that the connection with the Raven cycle must be considered secondary. Whether Raven really represents the moon, thus becomes immaterial for the immediate subject in discussion. Tuming to the probable home of the fully dereloped Northwestern type of trial-tales $(3: 334)$, the Nutka hero, Anthtine, has alrearly been discussed. The Nimkish join the tests to an ancestor tale. After the deluge a sea-monster appears from the depths of the ocean, carrying a human being, who is set down on the earth with his son Gyii. They are met by the transformer Kanigyilak, who fails to overcome them in a 
trial of strength. At length the father, who has assumed the name Guanalalis, is, in accordance with his own wish, transformed into a river. Gyii wooes a chief's daughter, is tested, and becomes the ancestor of a tribal division. In the entire myth there is hardly the suggestion of a solar feature, let alone the entire complex.

The Comox, a Kwakiutl, and a Newettee version seem at first sight to be more farorable illustrations of the nature-mythological theory: for the Comox heroes are sons of Aielen, the Sun; and Kanigyilak, the hero of the other tales, is the transformer, whom Ehrenreich persistently identifies with a celestial being. It is therefore necessary to determine the traits of these heroes with special reference to conceivably solar characteristics.

\section{THE TRANSFORMER CICLE.}

What seems to have impressed Ehrenreich in the wanderer cycle is the occurrence of twin brothers representing the "natural duality of sun and moon" and their descent from the sky. $(33: 45,56$.) An unprejudiced survey of the facts eliminates these grounds for conceiving the transformers as solar heroes. It is true that in the "Indianische Sagen" there are two instances of brothers descending from the sky; but Professor Boas has informed me that additional material from the Nutka and Newettee makes it, in the former case, highly probable that the descent from hearen is a secondary feature, and that his recording it among the Newettee resulted from a misunderstanding. As for the duality of the culture-hero, the Tillamook and Hupa have a single wanderer, while among the Chilcotin and nearly all the Salish there are four transformers. The assumption that in the latter case the extra pair represent the morning and erening star derives no confirmation from a study of the mythology of these tribes. They are nowhere expressly identified with these bodies, and it is difficult to imagine what actions of theirs could possibly lend countenance to such a theory. It is interesting to note that in the Comox version the hero's companions have animal names. The celestial nature of the transformer must therefore be defended on other grounds. Combining the common characteristic of all wanderer tales, i. e. the hero's ability to transform his enemies into stone, with the most widely distributed traits tabulated on p. I40, we find only one feature which fits into the naturalistic scheme. The highly characteristic trials of strength, the adventure with the enemy preparing against the heroes and turned into a deer, the breaking of the spear-point, and the final transformation of the transformers into stone, are all inexplicable on the naturalistic theory. There remains the restoration of the dead brother with its allegedly lunar significance. The artificiality of such a construction can, however, be easily demonstrated. An isolated feature of this sort would at best be merely sug- 
gestive. But the lunar hypothesis involves a solar interpretation of the other brother or brothers; and solar traits, as already mentioned, are not to be detected in the typical adventures of the cycle. The fact that in all cases but one the resuscitated wanderer, together with his companions, is ultimately transformed into stone, instead of being translated to the heavens, is an additional difficulty in the way of a lunar hypothesis. The artificiality of such celestial interpretations is similarly brought out in Hill-Tout's Skqomic myth. Here the Sun, who appears as an enemy of the four Qais, abducts and beheads the youngest brother; but the head is retrieved, and the youth revives. Now, following the traditional school of hermeneutic mythology, the opposition of the four brothers to the Sun might be treated as a sure indication of their lunar nature, which would be further illustrated by the dead Qais's resuscitation. The arbitrariness of this standpoint hardly requires proof. It suffices to point out that it is not the oldest and most important Qais that is killed and revived, that the antagonism of the four brothers to the Sun is confined to the single Skqomic myth (Hill-Tout), while the various Salish transformer myths go back to a common origin, and that on this lunar hypothesis the solar theory otherwise held with respect to this cycle is abandoned. Thus, the plot of the wanderer tales in no case justifies the naturalistic theory so confidently propounded. There remains, however, one tale, Boas's version of the Skqomic myth, in which the transformer is a single hero identified with the sun. The question arises, whether in this test-case the hero is a solar being, or whether the solar name is merely a later addition. The evidence for the latter assumption is really overwhelming. In the first place, the fact has been sufficiently dwelt upon that the incidents of the cycle show nothing resembling the solar complex. Secondly, we have every reason to believe that this form of the story is not primitive. Not only is the story extremely fragmentary, but the term Qais, which the Salish, as we now know, applied only to a group of brothers, refers, in the version discussecl, to a single being. In the much fuller version of Hill-Tout $(47: 5$ I 8$)$ the usual quadrumvirate bears no relation to the sun, while the strictly homologous and far more elaborate variants from the Fraser River and the Stseelis emphasize the descent of Qäls from a woodpecker (magpie) and a bear. $(3: 56 ; 49: 360$.) Thus, the case most favorable for testing the pretensions of the naturalistic theory furnishes an ideal instance of the secondary association of a solar name with the hero of a non-solar folk-tale. The celestial conception of the transformer is uniformly untenable.

To return to the main subject, the connection of the trial-tale with the transformer cycle in the Kanigyilak myth in no way supports the solar interpretation of the test-theme: first, because that connection itself is exceptional and secondary, as a glance at the table shows; 
secondly, because the transformer, as just proved, is not a celestial being in his actions.

There remain the solar connections of the Comox version, the fullest of all. Here we have two brothers, the sons of Aielen, the Sun, who ascend to the sky, are tested by Tlaik, the chicf of the upper world, and win his daughters. As soon as it is clearly understood that a solar or lunar name, or descent, may signify absolutely nothing as to the tale, but simply implies that the sun and moon are conceived as personal beings, the naturalistic theory again loses ground. The action connected with the heroes consists exclusively of the visit to the sky and the trials undergone. The ascent to the sky has been shown to be a free and indifferent element of Northwestern folk-lore. In the absence of the complete chain of solar criteria, especially of those traits which, like the swallowing episode and the capture of the sun, seem most amenable to a solar interpretation, Aielen's sons cannot be considered anything but the heroes of a folk-tale. Thus not a single hero of Northwestern trialtales can be safely identified as a solar character.

The conclusions hitherto reached may be summarized as follows:-

I. There are numerous stories of tests connected with human heroes and not related to a visit to the sky.

2. The most frequent feature of trial-myths refers to a social, not to a celestial phenomenon.

3. The test-incidents do not assume a specific character in tales relating a visit to the sky.

4. The trip to the sky is not a characteristically solar trait.

5. Tested by the solar norm, the heroes of the Northwestern coast are not solar beings.

6. Hence a character with explicit solar connections (Aielen's sons) is not in its origin necessarily a solar being.

7. A character explicitly identified with the sun (Qais) may have been secondarily associated with indifferent episodes.

\section{SOUTHWESTERN TEST-TALES; SECONDARY COMBINATION OF CELESTIAL CRITERIA.}

Turning our attention to the Pueblo myths, we find again that, with the exception of the spikes on which the heroes are cast, all the test-incidents occur in other combinations. The spine-seat, it should be noted, does not occur in all the Pueblo tales, but only in the Navaho version; in view of the general similarity of the Cherokee tradition, the recurrence of the motive in that tribe may be accounted for by borrowing. The same explanation may be given for its occurrence in both the Northwest and the Pueblo region. (13: 373.) On the other hand, the motive which appears in the three Pueblo versions, as well as in the Cherokee variant, the heat-test in the form of the sweat-lodge or boiling, has been shown 
to be a very widely distributed feature. The smoking-test is equally prominent among the Wintun and Yana, and appears as a smokingmatch among the Shoshone and Kitkehahki. (30: 77,78 .) The conciliation of guardian beasts by means of medicine and magic formulas represents, from the naturalistic point of view, a later ritualistic element. The dangers encountered by the Navaho twins are quite intelligible as the adventures of the errant boy heroes of human folk-tales. So far as the first part of the Southwestern myths is concerned, magical birth, a visit to the Sun, and the descent from a celestial being, are the only solar criteria joined with the test-theme. The second part of the stories, in which the war-gods combat evil beings and redress wrongs, can be discussed only in connection with the Prairie hero-tales, which, in the tables given on pp. I $39 \mathrm{et} s e q$., have accordingly been similarly divided into the account of the hero's birth and youth and his later adventures. The most striking point, in looking over the complete Blood-Clot, Star Boy, and Lodge-Boy cycles, is the remarkable similarity of the first portion, which may easily be brought under a single formula, and the considerable differentiation of the sequel. For example, the cssential features of the birth of Lodge-Boy and Spring-Boy are identical in nearly all the tribes; while the persistence of indifferent details, such as the stranger's insistence on having the food served on the woman's body, clearly indicates which versions are most closely related. In the sequel it is incleed also clear that the amalgamation of the Found-in-Grass theme among the Blackfoot, Gros Ventre, and Arapaho goes back to a common origin. On the whole, however, there is decidedly less similarity in the second part of our twelve versions. This is due not merely to the accretion of specific ogre-conceptions and the like, but also to a considerable alteration of the heroes' character. While in several versions the twins have the obvious mission of conquering evil, this trait becomes obscured in others, and disappears among the Ponca and Sauk, where the emphasis is on the mischievousness of the boys, while in the Sauk and Cherokee versions the antagonism between parent and boys is distinctive. Nevertheless, though few of the tales are bodily derived from other versions, it is impossible to deny that there has been a certain degree of historical connection not only among the versions of the Lodge-Boy cycle, but with the Pueblo twin myth and other hero-tales as well. The mischievousness of the Ponca heroes, for example, is quite in keeping with the character of the Zuñi war-gods $(85: 57)$, and the pretended flight from a dead monster in order to frighten the parent is so characteristic that we cannot assume a distinct origin for the episode among the Tusayan, Skidi, and Sauk, or the analogous incidents of the Ponca version. We must postulate a common origin for the Roc motive; and the hoop motive of the Jicarilla is beyond doubt related to that of the Prairie myths, especially as found in the Blackfoot variant. The Pittheus motive 
occurs in nearly all the hero cycles discussed, and the frequent mention of the cliff-ogre feeding his relatives or pet animals on the travellers hurled below indicates that this conception also has been widely borrowed. Still more important, on account of its alleged nature-mythological character, is the distribution of the sucking-monster; for it must be noted that, although swallowing is an incident everywhere found, the form in which this incident occurs in these tales is a highly specialized one. That the people of the Northwest, of the Prairie, of Greece and western Asia, have all developed tales of herocs swallowed by a monster, is conceivably explicable by a naturalistic theory; but the special analogies of Tlesea's and Tlendixtcux's swallowing by an elk or moose $(3: 3 ; 36: 10)$, or that of the Comox Mink and of the Tlingit Raven by a whale, can be accounted for only by borrowing. In the Menomini, Ponca, Osage, Crow, Dakota, and Tusayan swallowingtales the hero is drawn in by a sucking-menster, finds many people inside, pierces the monster's heart, and liberates the victims. $(26: 42$.) The occurrence of the same special traits in the same continuous area, in which borrowing is known to have taken place, can again be explained only by assuming a common origin. The killing of the gigantic ruminant with the aid of a burrowing animal occurs not only in the Southwest, but among the Dogrib Indians of the North, and in the same characteristic combination with the Roc episode. $(69: 324,325$.$) As$ both are found among the Jicarilla and Navaho, they may be considered elements of Athapascan folk-lore which have been incorporated by other Pueblo tribes.

The separation of the first and second portions of the Pueblo twin myth thus appears justified. The test-theme developed by this group of tribes is not indeed sharply separated from that of other tribes in the single incidents, but represents a distinct type owing to the unique relations of the actors. The second portion of the myth cannot be considered anything but a compilation of elements derived from distinct sources, and secondarily amalgamated with the tale of the twins' trials. A similar conclusion holds for the Blood-Clot, Star-Boy, and LodgeBoy cycles. The first parts are well-defined, sharply differentiated types of folk-tales; the second parts are infinitely variable, because they have developed independently and by accretions from various centres of distribution.

The fact of dissemination, as usual, is not immaterial in testing the legitimacy of the naturalistic hypothesis, but of fundamental importance, because it illustrates how the complex of solar criteria may develop sccondarily. Comparative analysis, here as elsewhere, proves to be a double-edged sword. If we selected the Blood-Clot myth of the Gros Ventre for interpretation from a naturalistic point of view, we could discover a fairly complete series of celestial traits: development of a 
child from blood (magical birth), rapid growth (lunar feature), falling trees (symplegades motive), sucking-monster (swallowing), tests. Our comparative analysis shows that the test-incidents are derived from the same source as the corresponding episodes of the Arapaho or Cheyenne, where the trials form a distinct tale with an anonymous, indeterminate hero. The sucking-monster is identical with that treated above, i. e. has been derived from the same source as that of the indeterminate Osage boy, the Menomini Michabazo, Ponca Rabbit, Crow twins, Dakota Star-Boy, and Hopi war-gods. $(26: 42$.) The origin from blood and the details connected with it are beyond any doubt bodily derived from the same source as the Arapaho, Blackfoot, Pawnee, and Dakota variants, in all of which the test-motive is lacking, while the swallowingmonster is found only in the Blackfoot myth.

The point is equally well brought out by the Star-Boy cycle. If we selected the Dakota star-hero, we could again find satisfactory eridence of a celestial being. The hero is explicitly connected with a star, is swallowed, and combats the spirit of evil weather. Several points are to be noted here. In the first place, the most prominent episode of the Skidi, Arapaho, and Gros Ventre legends, the attack of the rectum-snale repulsed with the celestial father's aid, is, from a nature-mythological point of view, indifferent. If Ehrenreich really disregards correspondence of mythological figures as compared with correspondence of motives, ${ }^{1}$ he must recognize that the Star-Boys of these tales are not at all identical with the Star-Boy of the Dakota. Neither do they represent a degenerate version of the Dakota myth, for the incidents are welldeveloped among the Gros Ventre and Arapaho, and form an entirely different plot. Folk-tales of a widely divergent tenor are thus narrated of a hero of celestial descent. Thus, the principle recognized by Ehrenreich in the abstract, but nowhere employed by him as a check in his interpretations, the principle that a hero's name is insignificant, is again exemplified. Secondly, the descent from a star must be considered a secondary trait of the wandering knight-errant's tale, not only because the most significant trait, the sucking incielent, is found in totally diverse tales, but because the birth of a Star's child is itself a secondary development of the characteristic star-marriage episode with which all the myths open. In the two Nicmac versions the two women raised by the stars escape with Badger's aid after promising to marry him. Their flight from Badger is described in eletail; there is no mention of a Star-Boy. $(71: 160,308 .)^{2}$ In the Wichita story the woman descends by a rope, and is finally carried down by buzzards; in the

1 "Stucken betont mit Recht, dass es nicht auf Übereinstimmung der Gestalten sondern der Motive ankommt," etc. (33: 7 r.)

2 A similar version, told by an Assiniboine at Morley, Alberta, is in the writer's possession. 
Coast Salish and Quinault rersions the boy hero is also lacking, though the latter is amalgamated with a long description of an ascent to the sky. $(27: 298 ; 3: 62 ; 35: 107$.$) What has taken place in the Dakota$ myth is fairly clear. The typical boy hero of the Plains has been given a celestial genealogy by amalgamation of his tale with the star-marriage theme. Finally, the Kitkehahki and Kiowa myths clearly inclicate that the twin motive may derelop secondarily. Star-Boy is in all other instances a single hero; in these two instances, evidently owing to the influence of Pueblo mythology or the Lodge-Boy cycle, the hero is doubled by splitting in two (cf. $70: 49$ ), or by association with his brother by adoption.

Comparative analysis no more supports the naturalistic explanation of the cycle of Lodge-Boy and Thrown-Away. Ehrenreich regards the origin of one boy from the afterbirth as a lunar trait. Upon what this interpretation (34: 602) rests is not clear to me. At all events, a glance at the table on p. IfI shows that this is a specifically Caddoan rotion, which has probably no fundamental significance. The death and restoration of the twins' mother may also be a special, though more common, derelopment of the tale. Against these faint suggestions of celestial features - always disregarding their equirocal character - we have the essentially human setting of the stories and the indeterminate parents. Even in the Cherokee version the parents' appearance in the sky is a later evolution from their originally human condition. The second part of the cycle having evolved independently of the beginning, the combination of quasi solar and lunar traits, where it occurs, must accordingly be considered inconclusive. For this reason the fact that the Cherokee twins are subsequently identified with the Thunder-Boys is not to the point. Moreover, it will presently be shown that such final transformations are not to be considered in interpreting the character of the preceding narrative.

For the Pueblo myth, howerer, this line of argument is not conclusire. A definite refutation of the naturalistic theory depends on the available material. It is demonstrable that all the trial-incidents found in the Pueblo versions are also found in other combinations. It has also been shown that none of the adrentures related in the second part can be used to enforce the naturalistic argument based on the initial portion. Nevertheless, we are still confronted by the combination of the testtheme with the visit to the sky, descent from the sun, and magical birth. In Pueblo mythology there are not, as on the North Pacific coast, human heroes undergoing precisely the same adventures as the Sun's children; nor can it be directly proved, as in the case of the Star-Boy and BloodClot cycle, that so-called criteria hare combined secondarily. My objection to the naturalistic interpretation of this case rests on the general principle that no criteria distinguishing celestial from human heroes 
exist, that explicit solar connections are accordingly insignificant. 'This principle, already illustrated by a limited number of examples, is most conclusirely established by the proof that an indifferent tale may, as in the myth of Qais, acquire a celestial aspect. In the same way it is possible to dispose of the theory that in some cases the plot has a solely explanatory function. When it is shown that colestial names and expla nations of natural phenomena are joined to independently developed tales, the naturalistic theory becomes untenable. I shall accordingly furnish additional examples of secondary association.

\section{EXPLANATORY MYTHS.}

According to the naturalistic theory, constellations are apperceived by primitive man as objects or persons according to the characteristics that appeal to him, and an explanatory tale is added. The phenomena are brought into relations with each other, and a story develops, one conception naturally leading to another. If the earth happens to be the scene of the plot thus evolved, the actors are simply transferred to the stars. $\left(33: 3^{8}\right.$.) This conception of astral myths is essentially related to the theory generally held as to the development of explanatory myths in a wider sense. That explanations of biological and other phenomena have developed cannot be doubted. The question is whether the tales united with the explanations are the outgrowth of an explanation or have developed separately and become secondarily added. Von den Steinen, has taken the former point of view, and tried to show in detail how the development may be conceived. In a South American story Turtle and Vulture have a flying race to the sky. Turle hides in Vulture's hamper, greets him at the goal, and claims the victory. They agree to race back, Vulture flies down, but Turtle just drops to the ground. In consequence his back is cleft, as may be seen to-day. According to Von den Steinen, the tale originated as follows: The native observes the cleft and infers that it must have been caused by a fall from a great height, such as the sky. To explain how Turtle ever ascended so far, he supposes that he was carried up by Vulture. The particulars of the flight are accounted for by assuming a trial of swiftness. $\left(8_{3}: 356,357.\right)$ Though this explanation cannot in the absence of comparative material be definitely refuted, it is very artificial. It would be extraordinary if a chain of reasoning were required for the production of a simple animal tale. The principle on which this interpretation is based, the principle that the perception of a fact to be explained must have preceded the story, proves untenable in its generalized form. ${ }^{1}$ In the first place, we do not know whether the explanation, instead of being the basis of the tale, is not merely the proof of the story. Just as the definite scene of the plot is often indicated

1 “. . . es ist ja klar, dass die zu erklärende Thatsache nicht zu der Geschichte gekommen sein kann, sondern nur die Geschichte zu der Thatsache." $\left(S_{3}: 356.\right)$ 
by the narrator to prove that he has given the historical facts, just so the peculiarity of the animal in question may be used to verify its action in early times. This theory seems plausible for such incidents as the scorching of an animal during the theft of fire. Ehrenreich, in his interpretation of Michabazo, insists that the Great Hare is in no way connected with the animal, but represents the moon; his getting spotted in capturing the fire merely describes the lunar spots. (34:570.) But in a Shoshone tale recorded by myself, the Cottontail (Rabbit) is delegated to shoot the Sun, and is scorched by it, whence his yellow spots. There is no reason for denying that the explanation of the Cottontail's spots as due to scorching has developed independently; but the appearance of the explanatory element in the story is simply a secondary matter, and in its present combination it is probably the demonstration of what precedes. There is nothing more likely than that the same interpretation holds for Michabazo; at all events, it is less artificial in accepting the name of the hero as given, instead of explaining it away as referring to the hare in the moon (Mondhase). Returning to Von den Steinen, we must note secondly that the application of his principle frequently leads to contradictions. In a Navaho legend Coyote learns the trick of sending his eyes away and recalling them. He is warned not to try the trick too often, but disobeys, and fails to recover them. He subsequently secures orbs of pine-gum, hence his yellow eyes to-day. Exactly the same story is told by the Arapaho, but with a different explanatory feature. The hero borrows Mole's eyes, hence Mole is blind nowadays. In a Shuswap variant the explanatory feature is entirely lacking. $(6 \mathrm{I}: 90 ; 3 \mathrm{I}: 5 \mathrm{I} ; 3: 8$.) Were either of the other versions lacking, the Shuswap form might be accounted for by the loss of the explanatory features. As it is, the same tale obviously cannot have arisen independently from two entirely different facts. Explanatory statements have simply been tacked on to a previously existing tale. ${ }^{1}$

Professor Boas has kindly called my attention to another unexceptionable instance of the same process. In a Shuswap tale recorded by Mr. Teit, ${ }^{2}$ Grasshopper refuses to help his people in storing up salmon for the winter, preferring to dance and eat grass. Famished in the winter, when the grass is covered with snow, he asks for food, but is told to play and eat grass. When nearly starved to death, he is transformed into the animal. "Henceforth," he is told, "you will be the grasshopper, and, as you were too lazy and thoughtless to catch salmon, you shall live on grass, and spend your time jumping around making much noise." This story is obviously a duplicate of the Æsopian fable retold by La Fontaine under the title of "La Cigale et la Fourmi." Knowing that

\footnotetext{
${ }^{1}$ Since writing the above, I have found a similar criticism of Von den Steinen's reasoning in Frobenius's Das Zeitalter des Sonnengottes, pp. 20-24.

2 Teit, The Shuswap (Publications of the Jesup North Pacific Expedition, vol. ii, p. 655).
} 
the Canadian voyageurs participated in the story-telling of the Indians, ${ }^{1}$ we may be quite certain that the fable reached the Shuswap through this medium. As the Shuswap have a considerable number of similar origin tales, it illustrates the tendency of a borrowed story to become adapted to a prevalent literary cast. 'The explanatory close is thus again an acquired feature.

\section{STAR-MYTHS.}

Applying the principle thus gained to the study of star-mythology, we ask: Are the nature-mythological conceptions which undoubtedly have developed from observation of the firmament the starting-point of the tales connected with them, or have these tales developed independently and become secondarily joined with the nature-myth proper? The Pleiades tales have been pointed out as classical examples of naturemyths, and the occurrence of such tales in all parts of the globe has been said to exemplify the psychical unity of mankind. Now, it need not be denied that the nature-mythological personification of this constellation has led to simple explanatory statements. The Fraser River myth reads as follows: "Qäls went on and found a group of children who were crying because their parents had left them. $\mathrm{He}$ transferred them to the sky, and they became the Pleiades." (3:21.) Here the apperception of the Pleiades as a group of children is, of course, the nature-myth, their transference to the sky by the transformer may be justly considered an "explanatorische Hinzudichtung." But it is doubtful whether full-fledged tales develop in this way. In a Cheyenne story a young woman is married by a dog and gives birth to seven puppies. Her husband leaves with the children, and is followed by the woman. Suddenly the tracks stop. "She looked up, and there she saw seven pups; they were stars." (5+: $18 \mathrm{I}$.) The numerous variants of the story among the Eskimo, Athapascan, Northwestern, and Plains tribes lack the astral feature at the close. At the same time, the number of puppies in the several versions varies considerably, from two to ten. What has taken place among the Cheyenne is perfectly clear. The condition for the development of a Pleiades tale is the presence of seven actors forming a group. In a region in which astral transformations are common the presence of a group of beings tends to amalgamate with the independently developed personification of the Pleiades, and this accounts for the Cheyenne form. The Cheyenne story well illustrates the principle that the type of association found in a given case is to a considerable degree conditioned by the specific type, or formal setting, of plots found in a cultural area. For example, Eskimo folk-lore, as Boas has shown (Io), is essentially human in setting. There are no complex animal tales; the strictly indigenous portion of Eskimo mythology is made up of 1 Teit, The Shuswap, p. 621. 
hero-tales bearing a very gencral resemblance to those of eastern Asia. On the other hand, among several Plains tribes, notably those of Caddoan stock, folk-lore tends to assume an astral aspect, while the Kwakiutl and kindred tribes most frequently relate the meeting of an ancestor with a supernatural being and the consequent acquisition of a dance or charm. (14:7, 25, 36, 107, 247, 255, 382, 403.) We might therefore expect that in the case of widespread narratives the same tale might appear among the Eskimo in human connections, while the Pawnce version would be joined with an astral milicu, and the $\mathrm{K}$ wakiutl variant with a tale of ritualistic acquisitions. This is actually the case. Among the Eskimo the story of the dog-husband is either joined with the Sedna myth, or accounts for the origin of alien tribes. In the Heiltsuk version (I4: 40I-403) the dog's offspring meet spirits from whom they learn the winter dance. In the Cheyenne version we found a Pleiades ending. Differently from all these, the Chilcotin variant is combined with one of the typical Pacific traditions, the transformer cycle. Under the circumstances, it would obviously be a monstrous assumption that the tale of the dog-children originated among the Cheyenne as an explanation of the Pleiades. We may safely assert that the story of the dog marrying a girl is the primary element in all the versions, and has in each tribe become assimilated to the conventional mould, or united with some important tribal myth.

The secondary assumption of a nature-mythological aspect is also very clear in a Pawnce tradition. Here the rattling skull, one of the commonest features of North American mythology, is the pursuer; the heroine begs a number of animals for assistance in a series of characteristic dialogues, and creates obstacles by means of magical objects. She is sared by several brothers, with whom she finally constitutes the Pleiades. (30: II 9.) The widely diffused elements making up the substance of this story occur in such a varicty of different combinations that any explanatory function in connection with the observation of the stars is inconceivable. Neither can the Shoshone tale of Coyote and his daughters, which ends with a Pleiades transformation (60), have originated in this way, for this element at the close, and the prerequisite condition that a number of characters be united in a group of six or seven, are both lacking in the Maidu, Ute, Navaho, and Pawnee versions. (25: $270 ; 55: 268 ; 62: 27 \mathrm{I} ; 30: 430$.) In other cases, however, the naturemythological view may, at first sight, appear equally plausible. In a familiar Plains legend a girl turns into a bear, and after killing the tribesmen pursues her brothers, who ascend to become a constellation. $(27: 69 ; 31: 152 ; 91$.$) The absence of the astral element in the Coos$ (75) and Ponca (32: 292) versions might be explained by degeneration. That this would be an artificial theory becomes manifest on examining a series of myths from a tribe whose mythology abounds in astral trans- 
formations. For the sake of illustration, I shall briefly summarize a number of Wichita stories.

I. A woman turns into a man-eating bear and pursues her seven brothers, who ascend to the sky by means of a feather and form the Dipper. (27:69; cf. $32: 292$.)

2. Coyote, disguised as a woman, is married by seven brothers. She tries to abduct their child, but is overtaken. The brothers then form the Dipper. $(27: 74$.)

3. An ogre lures a woman away. She escapes and is pursued by her husband, who is killed by a powerful old man. The wizard's seven sons marry her. The old man gets dissatisfied and takes the entire family to the sky, where they become Ursa Major and the North Star. $(27: 63$.

4. Coyote obtains supernatural power, but is warned to keep away from women. He yiclds to temptation, becomes an animal, and Iosi's all his power. His adopted son makes a formal announcement to the people of what has happened and of his intentions, and becomes the Morning Star. $(27: 30$.)

5. Flint-Stone-Man goes on the war-path, ordering his wife not to send her son after him before he is of age. The youth grows up, and joins his father. The old man declares his intention of becoming the great South Star. The youth returns, summons a council, makes the formal declaration, and becomes a star like his father. $(27: 47$.

6. Poor Wets-the-Bed outdoes other warriors and wins the chief's younger daughter. His sister-in-law at first despises him, but falls in love and tempts him when he suddenly becomes handsome. He decides to go away, makes the customary announcement, and becomes a star. Most of the people become animals. (27: 106.)

7. Child-of-a-Dog, owing to the trouble he has had, becomes a wind, his wife changes to a raccoon. $(27: 120$.)

8. A chicf's son marries a girl, but does not acknowledge her as his wife. She becomes an eagle and flies away with his child. Her husband then becomes an otter. $(27: 167$.

9. The hero's son is taken away by a witch. The hero stays by the water looking for his child, and after the formal announcement turns into a flamingo. $(27: 172$.

I0. A young chief carries a burr-woman on his back. Turtle succeeds in shooting her off, but the old chief fears further misadventures, and after the usual declaration the entire family become eagles. (27: I 87 .)

I I. A man who gambles for life is beaten by Half-a-Boy, who decides to become a blackbird. $(27:$ i 94 . $)$

12. A bad boy reforms and becomes a powerful warrior. He remains unmarried, and finally becomes a hawk. (27:257.)

I3. Wets-the-Bed, after performing warlike deeds, becomes a shooting-star. (27: II 4 .) 
XII. REASONS FOR ASSOCIATION; ADDITIONAL ILLUSTRATIONS.

The common element of all these tales is the final declaration that, owing to certain conditions or happenings, the hero has decided to assume a non-human shape. What he changes into is immaterial. It may be an eagle, or an otter, or a flamingo, yet no one supposes that the tales joined with these transformations are in any way explanatory. It is quite arbitrary to select the tales with astral endings and assume that they are explanatory. In either case, however, there is direct eridence to the contrary. The adventure of the hero with Burr-Woman cannot have been developed as an explanation of the origin of eagles, for the incident occurs in an entirely different context in the Ponca twin-myth and in other tales. Similarly, Wets-the-Bed's transformation into a star does not stamp his story as an astral myth because the identical tale of the tempting sister-in-law is found both without any transformation and with the hero's changing into stone. (3I:34I.) The lack of intrinsic relation between the astral aspect and the story proper also comes out in the Blackfoot twin-myth. It is merely necessary to compare it with the other versions to recognize the astral close as a secondary feature. We are thus warranted in concluding that in the domain of astral mythology the secondary identification of a human hero with a celestial body, instead of being merely a theoretical possibility, has repeatedly occurred. The fact that this type of association is farored in definite areas is unintelligible on the naturalistic theory. If star-myths are developed everywhere from observation of the heavens, why this extraordinary efflorescence of star-lore among the Pawnee and Wichita compared with its relative meagreness among the Eskimo and in the Northwest? That it results from the character of the complicated Caddoan ceremonies is at least a plausible hypothesis, just as the remarkable development of ancestor traditions among the Kwakiutl is easily intelligible from their social life.

Another factor in the development of association must, however, be recognized. Though the connection of the Pleiades with the Cheyenne tale is secondary, and though the astral relations are sufficiently accounted for by the foregoing considerations, the fact that the Pleiades rather than, as in other versions, some other constellation or single stars, are connected with the narrative, depends on the congruity of the number of actors with the number of stars in a group. Such congruity may result in other cases in a very different way without any necessity of interpreting the story as a nature-myth. In the Eskimo tale of the sun and moon a young woman is surprised by a man in the night. In order to detect her lover, she marks his robe, and discovers her brother. Angered by his conduct, she snatches up a light, and flees. He pursues, and falls, extinguishing his light. Then both are raised to the hearens, and 
become transformed into the sun and the moon. ( $1: 637 ; 5: 173,306$. ) For nature-mythological theorists the apperception of the moon as a lover pursuing his mistre:s is the starting-point of the story; the other incidents are explanatory. 'There are, however, difficulties in the way' of this simple interpretation. In a tale from the lower Fraser River and the Thompson River the human brother and sister commit suicide as soon as their son recognizes their relationship; but there is no transference to the sky, nor the pursuit. $(3: 37 ; 46: 566$.) The Tlingit have indeed the Eskimo myth, but as a variant. Chlkajage, marked by his sister, flees to the top of a mountain, flies away as a bird, and becomes the thunder, while the girl descends underground. In a third version the same metamorphoses occur without a precedent love affair. (52:268, 270.) In a Fraser River legend two marked lovers are the father's hammer and a splinter of wood. (3:4I.) The marked lover is a dog among the Carrier, Fraser River Indians, Bella Coola, Chilcotin, Skqomic, Arapaho, Cheyenne, and Blackfoot. (67:28;3:264;36: 10; $47: 536 ; 31: 207 ; 54: 181 ; 91$.) He is the woman's brother among the Eskimo, the Tsetsaut, Fraser River people, and Cherokee. (9:257;66: 256.) In two of Hill-Tout's Skeomic legends he is the guardian slave of the chief's daughter. $(47: 5 \mathrm{I} 2,549$.$) The closest analogue of the$ Eskimo myth is the Cherokee variant, in which both the relationship of the lovers and their transference to the sky recur; but in the Cherokee tradition the pursuit motive is lacking, as it is, of course, in all the other variants. It is therefore next to inconceivable that the story of the marked lover should have originated from the conceptions formed of the succession of sun and moon. It may be safely inferred that the story has developed independently. Just as the occurrence of seven heroes may lead to identification with the natural septet of the Pleiades, so the existence of two horoes may result in their association with the natural duality of sun and moon, - may, for very frequently no such association takes place. It is not at all improbable that the Eskimo conception of the sun and moon as pursuer and fugitive promoted the amalgamation. But here, as elsewhere, the nature-myth proper has not determined the course of the narrative. Its distinctive feature, in this case, is simply that, instead of merely representing some descriptive trait, it harmonizes with a subordinate element of the plot. In the absence of satisfactory evidence, we may continue to doubt whether cosmic or astronomical conceptions have ever resulted in genuine hero-tales. It must be remembered that in the numerous stories of visits to the sun or moon it is not the hero that is a solar or lunar being, and that the hero's actions do not, as a rule, serve primarily as an explanation of solar and lunar characteristics. To the concession made throughout, that descriptive traits and nature-mythological ideas may be interwoven with the fundamentally human folk-tale, it is merely necessary to add that the con-

voL. XXI. - vos. S1-S2. 
cept formed of a natural process may intrinsically fit in with the course of the narrative and become united for that reason.

It is interesting to note that the principle of secondary association, in a wider sense, has been recently recognized by an adherent of the traditional nature-mythological school. In an article on Mexican mythology (79) Seler endeavors to vindicate agamst Preuss the claims of lunar as opposed to solar hypotheses. The tennis court of Mexican pictography is interpreted by Preuss - in accordance with Seler's former supposition - as a symbol of the sun's daily journey: it is connected with the myth of Uitzilopochtli, the ball represents the sun, the water pictured on one side of it stands for the dawn, the skull on the left for the vanquished stars. Seler tries to show that a solar explanation is inconsistent with the direction of the ball's flight, and that the tennis court is very rarely represented with solar personages, but appears regularly with the earth-goddess, with Tezcatlipoca and Quetzalcouatl. Earth-deities are, on psychological grounds advanced in common with Ehrenreich and Siecke, identified with the moon. Quetzalcouatl and Tezcatlipoca are recognized as lunar beings. So far, Seler's interpretations are, of course, diametrically opposed in spirit to the standpoint here taken; but in rejecting Preuss's suggestion that the ballgame was originally not an amusement, but a form of imitative magic, Seler arrives at conclusions thoroughly in harmony with those here defended. The fact that a dramatic representation, or a game, is connected with magical beliefs, does not prove that it is essentially and primarily a magical performance. The harmless enjoyment of play, and the tendency to read a meaning into it, are psychological processes at least as strong and elementary as the wish to produce a desired result by imitative magic. The ball-game was primarily a means of diversion. Associated with a deity, it became sacred in this connection, the details of the game were correlated with the ideas pertaining to the god, and finally the game acquired a magical character. (79:9.) Exactly the same criticism is advanced by Professor Haddon ${ }^{1}$ in a recent review of Culin's "Games of the North American Indians" with reference to cat's-cradle and the hoop-and-pole game.

It is difficult not to recognize the soundness of this argument; but the connection of tales with personified celestial bodies furnishes a close parallel to the association discussed by Seler. The harmless pleasure derived from the narration of a folk-tale is a psychological phenomenon that requires no cosmic or celestial relations to become intelligible. As Seler himself says, myths are not necessarily representations of natural processes, but are frequently enough "die freie Schöpfung der gestaltenden Phantasie." (79:22.) The rationalistic and associative tendency is likely to be as active in the history of myth-making as in the ritualistic

\footnotetext{
1 Nature, vol. 77 (igo8), p. 569.
} 
development of amusements. To be sure, psychological prubability is an inadequate proof. 'The question is whether these tendencies are demonstrable in the realm of mythology. When, however, this question is decided affirmatively, the justification for interpreting the elements of a story as representations of a natural phenomenon disappears on methodological grounds, even though secondary amalgamation may not be provable in each and every instance.

The importance of proving secondary association justifies the mention of additional examples. In one of several versions of an Arapaho tale the Moon lures a human woman to the sky. She leaves him, as in the Star-Boy myth, but is killed as she swings to and fro from the rope. Moon angers Buffalo-Woman, his second wife, by speaking of the human woman. She leaves with her calf, and is followed by Moon, whom her relatives subject to the typical buffalo tests cnumerated on P. I 37 . (31:321, 329,404 .) As these trials are in every other instance ascribed to indeterminate human heroes, and as this feature is lacking in several other Arapaho versions of the Moon's marriage to the woman enticed by the Porcupine, the secondary association of the test-theme with a lunar being is beyond reasonable doubt. In a somewhat different way the process is exemplified by the contest of the Skidi Spider-Woman with the sunyouths sent by Tirawa. The close of this story, the transference of the woman to the moon, falls under the general category of astral transformations already discussed. The substance of the plot has a number of close parallels in Pawnee folk-lore. In onc of these, Spider-Woman is not overcome by solar beings, but by two anonymous youths with supernatural power. $(30: 233$.) In another a witch is beaten in a race by the hero; she steals his robe, is whirled to the sky and back again by a tempest, and finally turned into a deer or spider. $(30: 222$.) A witch is overcome by the anonymous hero in a diving contest and killed by the people on the boy's side. (30: 225.) Another boy-hero is offered poisoned food, which he vomits. Spicler-Woman engages him in a climbing-match, but loses and is put to death. (30:219.) In one story it is a girl who conquers Spider-Woman in a ball-game; Spider-Woman is burnt and turns into a spider. (30: 236.) In another tale the cannibal prepares to kill her dancing victim, who is saved by the arrival of some Indians; the sorceress is burnt and becomes a frog. $(30: 2,10$.) The conflict of young heroes with the evil women believed to infest the Prairie is seen to be a common element in the folk-lore of this tribe. This would lead us to suppose that the contest of the sun-youths with SpiderWoman might not, after all, have anything to do with the opposition of sun and moon, as might be imagined at a first glance. But we know that Spider-Woman is an essentially beneficent being in Pawnee mythology, being sharply contrasted in this respect with the "witch-women." Under these circumstances, the most plausible hypothesis is that suggested by 
Dorsey, that a characteristic witch tale has become secondarily united with the myth of Spider-Woman's transference to the sky. (28:335, esp. note 78 .) Thus, a lunar being would again be shown to appear in an independently evolved tale. In the Arapaho version of the dog-husband myth the lover is identified with the sun. (3I:205-207.) This idea, lacking in every other variant, and found without a trace of solar traits, is obviously an afterthought. The Shoshone (6o) identify the Man in the Moon with a Dzoabits, i. e. one of the man-eating ogres who formerly carried off Indians in their bags. This explanatory statement is, however, not embodied in a tale; lunar traits are absent; besides, in one of Powell's stories a Dzoabits is transformed into the echo. $\quad(70: 47$. The association of the Skqomic Qais (Boas) with the transformer myth and of Aielen's sons with the test-theme has already been dealt with. Thus a secondary association of sun and moon beings with the heroes of indifferent tales has demonstrably occurred.

\section{RÉSUMÉ.}

Returning to the test-theme, we may now briefly review the general aspects of our problem. The test-theme in its fundamental ideas, the imposition of a difficult or clangerous task and a mutual or competitive trial of strength, is evidently derived from human experience. Its alleged function in solar myths is not the description of a natural phenomenon, but is avowedly explanatory. As a matter of fact, adopting provisionally the criteria of the naturalistic school, it has been shown that a majority of North American test-tales have human heroes and a human setting. The antagonism of suitor and father-in-law, which is characteristic even of the celestial stories of the Northwest, probably reflects a widespread social phenomenon. The substitution of the cruel uncle in Alaska is beyond doubt influenced by the social relations of uncle and nephew among the Tlingit and Haida. The North Pacific area often shows the union of tests with the ostensibly solar hero's visit to the sky; but the ascent motive turned out to be a free element of Northwestern folk-lore, lacking at times in explicitly solar myths, and appearing in indifferent folk-tales. The heroes descended from the sky or identified with the sun do not present the solar complex; and in the most complete versions a secondary association of the hero's heavenly relationships with the tests seemed highly probable. The remaining cases of tested solar heroes could not - possibly owing to lack of comparative material - be interpreted in this way. Here it was consequently necessary to raise the question already broached, whether the features emphasized in these stories really stamp the tale as a nature-myth. Returning to the Quiché and Pucblo tales, it is interesting to note, in the first place, that even they are not convincing from Ehrenreich's own point of view. The snaring of the sun with loss of limb, and the swallowing-motive, are 
lacking in both. The swallowing-episode occurs, indeed, in the Tusayan version; but its special analogy to the sucking-monster of the Plains, joined with its absence from other Pueblo variants, establishes the theory of a later intrusion. In both cases the complex of solar traits is thus reduced to magical conception, the journey to another world, and the test-theme,- a combination still incomplete; so that from a sane naturalistic point of view, as theoretically defined by Ehrenreich, ${ }^{1}$ a sceptical attitude would be required. There are, however, considerations that warrant a much more positive opposition to Ehrenreich's standpoint. Even this complex, deficient as it is, is not a common characteristic of the Northwestern and Southern tales dealing with explicitly celestial beings. The motive of magical conception is absent from the solar myths of the Northwest, occurring precisely in the human tale of Anthtine. Furthermore, the equivalence of a journey to the underworld and a trip to the sky, while defensible if the naturalistic theory is taken for granted, remains to be proved when its fundamental assumptions are challenged. Thus, the only element common to the solar test-tales of North America is the element shared by the human tales: the occurrence of tests. The result of our discussion may accordingly be summed up as follows: Assuming the establishment of celestial criteria, and testing the heroes of our trial-tales, we have not found a single instance in which the complex of traits is entirely or approximately represented. Comparing, on the other hand, the ostensibly solar heroes, we are not able to find any traits distinguishing them as a class from human characters.

It is, however, the examples of secondary association that strike at the root of the naturalistic theory. If the hero of a tale is secondarily transformed into the sun, or acquires a solar name, his newly developed solar affiliations have evidently not influenced the plot any more than the explanatory statement tacked to a story, - whatever may be the traits ascribed to him. The unreliability of even a complex of criteria is exposed when the complex can be proved to have developed by amalgamation of disjointed elements (Star-Boy, Blood-Clot). On the other hand, when the incidents told of a hero subsequently identified with a heavenly body are indifferent, from the standpoint of the naturalistic system, the union of indifferent traits with a solar being refutes the fundamental assumption that a definite type of actions is correlated with solar names or lineage. If the supposed criteria are to be recognized as valid, they must be based on an unbiased enumeration of traits common to all explicitly solar or lunar characters. Contrary to the naturalistic dogma, our preliminary considerations indicated that such similarities were diffi-

1 "Also Verschlungenwerden und Wiederauftauchen, Unterwelts- oder Himmelsreise mit dem Symplegaden- und Probenmotiv, Schlingenfang und Beinverwundung, Haarverlust und magische Empfängnis u. a. müsste ein . . Mythologe bei seinem Helden wiederzufinden im stande sein." ( $34: 576$.) 
cult to find in the empirically given solar myths of the Thompson River Indians, Kathlamet, Cherokee, and Maidu, or the lunar myths of the Eskimo, Athapascans, and the North Pacific coast. Not only was conformity to a common prototype found lacking, but there were features directly contradictory to the naturalistic scheme. Petitot's lunar boy does not grow at all, the decapitated Moon of the Pacific coast fails to revive. The discussion of the test-theme furnished additional testimony, as the tested heroes of solar extraction did not show a complex of homologous characteristics. Combining with these the cases in which sun and moon are secondarily associated with folk-tales, the scope of celestial is seen to coincide with that of human activities. The Sun is a cannibal (Thompson River), an abductor of children (Maidu), the transformer (Skqomic), the husband of a frog (Arapaho), the marked dog-husband (Arapaho). He may in different versions of the same tale act as the cruel father-in-law and as the hero's abettor (Koryak); he is tester, as well as tested hero (Wintun, Yana, Pueblo, Northwest coast). The Moon assists the distressed (Eskimo), engages in a trial of skill (Tlatlasikoala), practises witchery (Pawnee Spider-Woman), is tested by the buffalo (Arapaho), is identified with the giant Dzoabits (Shoshone). Even the descriptive features are not confined within a narrow range. Why is the Sun conceived as blind (Kootenay), or naked (Thompson River)? Why are the lunar women invisible (Athapascan)? It is thus not the uniformity of the celestial hero's traits, but their indefinite variability, that is proved by the available material. Undoubtedly, a great number of nature-mythological concepts will be assimilated, which accounts for the wide spread of certain descriptive motives; but, so far as the tales related of sun and moon are concerned, far-reaching similarities distinguishing them as a group from human folk-tales cannot be detected. Solar and hunar heroes are human beings named after, or somehow identified with, sun and moon.

\section{A. - NORTH AMERICAN TEST-TALES PROPER.}

\section{Northwestery America. See table on page 135 .}

\section{Other North Pacific Test-Tales.}

(a) Chilcotin. A young man marries Thunder's daughter. He escapes from his father-in-law's bears, which have killed all other suitors. Thunder demands that the hero build a new house and clear his garden of weeds. By means of uncovering his head the youth succeeds, and flees with his wife. $(36: 26$.

(b) Chinook; Quinault; Wishram. Several men travelling from village to village are invited to contests by their hosts. They win in climbing-match, diving-contest, sweat house trial, ete. $(2: 56 ; 35: 102: ; 6$,

(c) Tillamook. Six human travellers pass the clashing lightning-door. One of them leaps in and is injured jumping out again, but is cured. They arrive at the chief's place. People try to stiffe them with their breath, but the visitors cause a deluge, in which their enemies are drowned. The heroes defeat their hosts in a hoop-game and kill them. (8: 30.$)$ 
The Test-Thicme in North American Mythology.

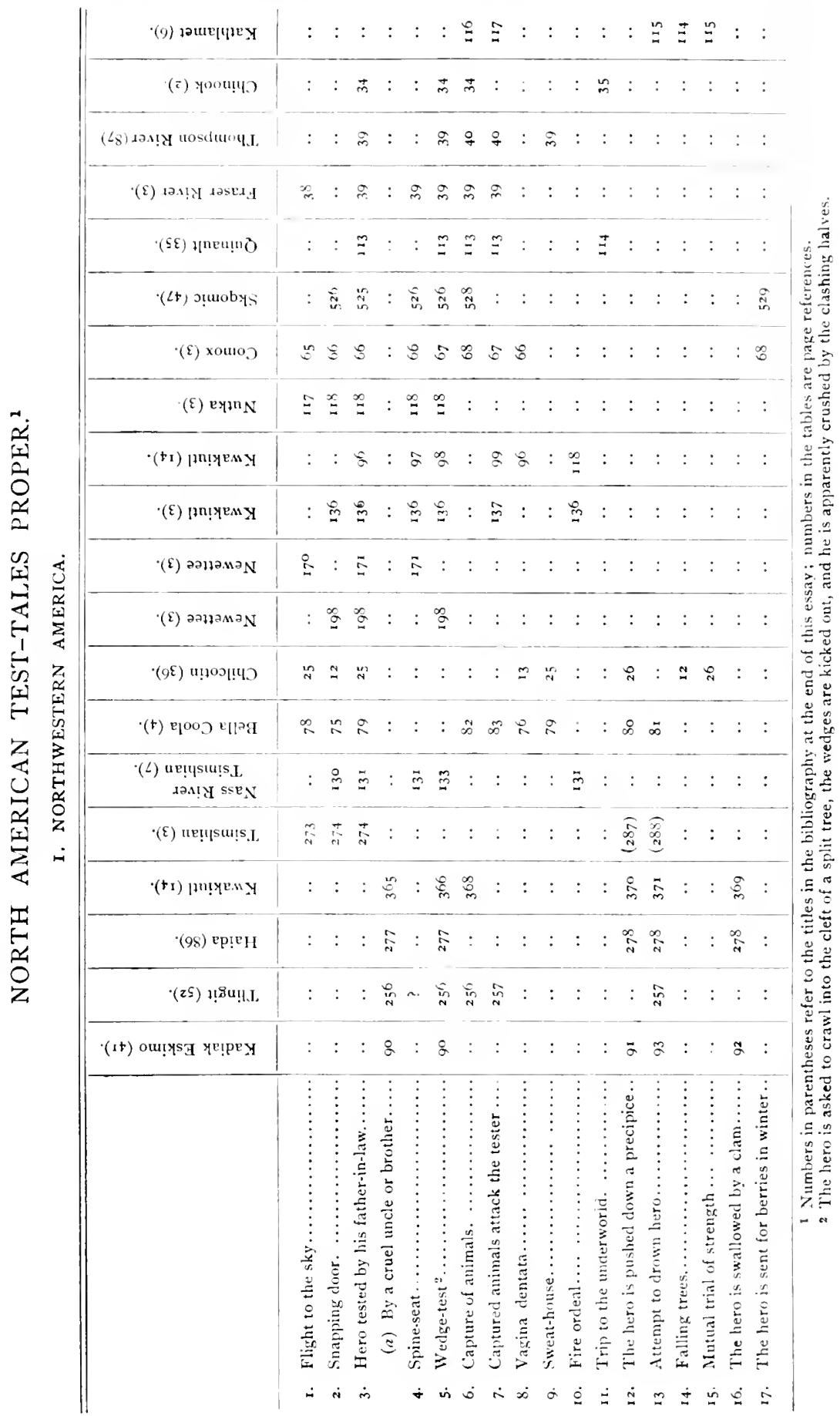




\section{Californta.}

(a) Hintun. An old woman digs a child (Tulchuherris) out of the ground, and brings him up. She warns him not to go to the east, but the youth disobers (Pittheus motive). He sets out for Sas's house to win his daughter. On his way he kills old men who try to push him over a precipice (cliff-ogre) and to drown him. Having passed through a snapping pine, he vanquishes Sas's guardian beasts. Tested by his father-in-law, he survives the sweat-house ordeal, smokes poisonous tobacco unharmed, and kills his host's Gorgon wife. Sas lures him to his monster children, but all are overcome. In a treepulling contest with his father-in-law, Tulchuherris wins, and hurls Sas to the sky, where he is split into sun and moon. (22: $\mathrm{r} 3 \mathrm{r}$.)

(b) Yana. Rainbow's son, aided by his uncle, goes in quest of Moon's daughter. He is not killed by Sun's poisonous tobacco, and, overcoming Moon in a pole-bending contest, hurls him to the sky. $(22: 287$.)

(c) Yana. Acorn-of-Black-Oak sets out with his uncle to woo two girls. He survives Moon's smoking-test, beats his brothers-in-law at a bone-game, and in a race slays the dangerous animals set against him, and finally kills his enemies with a staff. $(22: 430$.)

(d) Maidu. Thunder's daughter is followed by a suitor, whom she leads over a dangerous road. With the aid of flint, stone moccasins, and a feather, he surmounts the obstacles, and sleeps with the girl after breaking her tceth (vagina dentata). Arrived at Thunder's house, he swallows poisoned food without harm, breaks a log which has proved fatal to other suitors, eatches a dangerous fish, and, lured to a grizzly's haunt, kills the bear by hitting its only vulnerable spot. $(24: 67$.

\section{Southwestern Tales.}

(a) Sia. A virgin embraced by the Sun gives birth to twins. The boys visit their father in the east, and are tested by him. Sun puts them into a sweat-house, which they cool by spitting out shells. They are cast into the deer-house and the rattlesnake-house. As the animals do not injure them, they are recognized as Sun's children, and are sent to contend against monsters. $(84: 43$.

(b) Tusayan. The twins, counselled by Spider-Woman, visit the Sun. By spurting a charm they pacify a cliff-ogre and other monsters on their way. They enter by the clashing gate of the sky. Sun puts them into an oven and builds a fire. As they are not hurt, they are recognized as his sons. (38: I35.)

(c) Naz'aho. The twins, counselled by Spider-Woman, pass snapping rocks, crushing reeds, cactus-fields, whirling sands, and monsters which they conciliate with their magic formulæ. They arrive at Sun's house, are thrown on sharp spikes (spine-seat), put into the sweat-lodge, and subjected to the smoking-test. Remaining unharmed, they are recognized by their father. (6I: I08.)

\section{Cherokee.}

(a) A scrofulous boy (subsequently identified with lightning) is sent to his putative father, Thunder, to be cured. Thunder bids him sit on honey-locust thorns (spine-seat), and boils him in a pot. He is not injured, and reappears cured. He must select ornaments from a box filled with snakes. Obeying an old woman, he selects the snakes from the botton. Then he is obliged to fight his brothers, the Thunder-Boys, until separated by his father. His tests thus terminate, and he is prepared for his contest with a gambler. $(66: 312$.

(b) A man wishing to marry a woman is led to the cave of her brother, Thunder. He is afraid to sit on a turtle-settee, refuses to ride an uktena monster, and is struck senseless by his angry brother-in-law. (66:345.) 


\title{
6. Prairie Tribes.
}

\author{
(Buffalo-IVoman Myth.)
}

A man marries a buffalo-woman. She leaves him with their chilt. IIe follows her to the buffalo camp, where the buffalo subject him to tests. (So: $280 ; 32: 160 ; 28: 284 ; 27$ : $202 ; 29: 94 ; 31: 326,40.4 ; 54:$ I 86 .) He is obliged to recognize his wife and son among a great number of buffalo cows and calves, which he succeds in doing with his son's assistance.' Either he himsclf, or his son, must race against the buffalo. ${ }^{2}$ 'The animals try to hook him, but he flies away as a feather, and they merely gore onc another. ${ }^{3}$ (Other trials: Swinging-test, ${ }^{4}$ laughing-test,${ }^{5}$ dancing-test,${ }^{8}$ sweat-lodge. ${ }^{7}$

\section{Prairie Tribes.}

(a) Arapaho-Cheyenne. A powerful wizard sends his daughter's suitors to get arrowsticks, points, and feathers, and kills them if they fail. The hero suceeds, and is then required to capture a buffalo. The animal consents to accompany the youth, and kills the tester. $(31: 294 ; 54: 177$.

(b) Gros Ventre. Blood-Clot, after many adventures, marries a chief's daughter. He is required to fetch burning coal, arrow-wood, feathers, buffalo-sinew, and flint, and succeeds every time. He is sent for water, and is drawn in by an animal (sucking-monster), whose horns he cuts off. His father-in-law tries to kill him, but is himself slain. (56:88.)

\section{Miscellaneous Prairie Tales.}

(a) Ponca. A youth, accompanied by four comrades, sets out to marry a beautiful woman. Her fellow-tribesmen demand that the visitors remove a large rock, and defeat one of their women in a foot-race. One of the youth's companions wins the girl for him. (32: 33.3.$)$

(b) Wichita. A girl brings up the human offspring of a female dog and the Wind. The boy grows up rapidly. He is lured by a woman to climb a tree, to which he sticks until released by his father. He marries the woman's sisters, beats his brothers-in-law in a race by causing obstructions in their way, and is caught in a pit, but rescued. An old woman invites him to marry her daughters. He overcomes them (vagina dentata), killing one and marrying the other, with whom he flees from the witch's lodge (magic flight). (27: 130.$)$

(c) Skidi Pawnee. Evening-Star's daughter kills all suitors with her vaginal teeth. Poor-Boy, assisted by Morning-Star, surmounts the obstacles on his way to the girl's house, and conquers the guardian monsters. The girl asks him to get beavers' pappooseboards and a buffalo-robe. The hero secures the desired articles, breaks the girl's teeth, and marries her. $(28: 33 ; 30: 38$.)

(d) Skidi Pawnee. Spider-lloman poisons stray hunters. Tirawa sends the sunyouths against her. The heroes conquer dangerous beasts before reaching the witch's lodge. She offers them poisoned foot, which they vomit. She asks them to dance on a precipice, and tries to have them blown down, but they fly off as birds. They have her carried to the moon by grasshoppers, where she may be seen to-day. $(28: 40$.)

\section{Athapascan and Lake Algonquin.}

A youth is carried off by an old man, whose daughter he marries. $(67: 6 ; 73: 203 ; 78$ : 205.) The youth is sent to the thunder-birds, but returns safe. $(67 ; 73 ; 78$.) He has a flying-match, or swinging-contest, with his tester. $(67 ; 73$.$) He is taken to an island to$ fetch eggs and is abandoned, but fljes home as, or on, a gull. $(73 ; 78 ; \mathrm{ff} .69: 452 ; 18: 15 \mathrm{I}$; $72:{ }_{139}$.) He is offered to a man-eating fish, but is carried home by it. $(78: 207$.$) The$ old man burns the boy's moccasins to prevent his return, but the youth saves himself, and retaliates. (78:209; 18: г5 ; 61: 193.)

1 Crow, Ponca, Skidi, Wichita, Arikara, Arapaho (cf. $46: 544$ ).

3 Crow, Ponca, Skidi, Arikara. $\quad$ Ponca. 5 Ponca.
2 Ponca, Skidi, Arikara, Arapaho.

- Arapaho. $T$ Ponca. 


\section{io. Miscellaneous North American Tales.}

(a) Micmac. A young man marries a chief's daughter. He is required to move a rock and to defeat a hostile force; with the assistance of his manitou, he accomplishes both tasks. The old man orders him to capture a dragon: the hero succeeds, and kills his father-in-law with the monster's head. (7I:7.)

(b) Micmac. A youth marries in an upper world. His mother-in-law tries to kill him with poisoned food, which he rcfuses. She tries to throw him over a precipice in a wrestling-mateh, but is conquered by the hero. (7I:90.)

(c) Micmac. A young man captures a dragon for his father-in-law, defeats the sorcerer in a race and diving-match, and passes in safety through all the dangers put in his path. (7r:25.)

(d) Menomini. The father-in-law hurls a wildcat cloth at the hero, who throws it back at him. The old man sets poisoned food before him, but he refuses to eat. The hero wins his wife by leaping over the old man's wigwam. His mother-in-law demands that he get a white and a yellow bear's paw for her, which he succeeds in doing. In a retaliatory test imposed by the young man she fails. (50: 169 .)

(e) Menomini. Ball-Carrier defeats his witch sister-in-law in a race, and kills her. (50: 233 .)

(f) Navaho. Natinesthani marries a wizard's daughter. He is offered poisonous food and tobacco by his father-in-law, but is warned by the Winds and escapes injury. On a deer-hunt he is lured to the lair of wild beasts, and slays the old man's pet monsters. Far away from home the wizard intends to destroy the youth's foot-gear, but the hero exchanges the moccasins, so that the tester burns up his own. (6I: I75.)

(g) Zuñi. A girl, who keeps all the game concealed, asks suitors to shoot deer for her. All fail until the war-gods follow her to the corral and kill the animals. The girl next asks them to scrape all her buckskins within a day. With the aid of field-mice, they succeed. (23: ro.4.)

(h) Zuñi. A girl agrees to marry the suitor that will scare away wild beasts destroying her corn-ficlds. A poor boy succeeds, and marries her. (23:288.)

(i) Zuñi; Navaho. Several brothers promise to give their sister to the man that conquers a demon. Coyote by a ruse succeeds, and wins the girl. $(2.3: 215 ; 61: 92$.$) Coy-$ ote must then allow the girl to kill him four successive times, but is restored every time, and marrics her. $(6 \mathrm{I}: 94$.

(j) Tusayan. Tiyo wishes to réscue his wife from Man-Eagle. He sets out, assisted by Spider-Woman and Mole, and reaches the lodge. The monster proposes contests. The youth swallows the smoke from Eagle's pipe without getting dizzy. Eagle asks him to break one of two horns; counselled by Spider-Woman, he selects the brittle one, while Eagle fails to break the real antler. Eagle proposes a tree-pulling match. Mole gnaws up the roots, so that 'Tiyo wins. In an eating-match the hero defeats his opponent by passing the food through a hole dug by Mole. They are next to sit on an ignited wood-pile. Tiyo has stolen the monster's ice-coated armor and substituted a gum imitation. He survives, accordingly, while the Eagle perishes. (38: 134 .)

(k) Tusayan. Tiyo descends to the ocean in a box, conciliates Spider-Woman and guardian animals with bahos and medicine, is given tobacco by the chicf of the snakepeople (smoking-test), seizes one of the snakes after spurting medicine on it, and receives instructions. ( $90: 30 ; 37:$ 106.)

\section{QUICHÉ.}

Two brothers are killed by the princes of the underworld (Chibalba). The head of one of the slain heroes causes a princess to conceive and give birth to twins, Hunahpu and Xbalanque. The boys are summoned by the kings of Chibalba, pass unlarmed through the Rivers of Blood and Mud, and, contrary to their enemies' wish, discover their names. They refuse to sit on heated stones, succeed in keeping their cigars and torch unconsumed in the House of Darkness, defeat their hosts in a ball-game, and in the 


\section{The Test-Theme in North American Mythology.}

House of Lancers persuade the guards to spare their lives. With the aid of ants, they secure flowers from the testers' gardens, heat up the House of Cold, pacify the beasts in the House of Tigers, and remain unscathed in the House of Fire. In the House of liats Hunahpu is killed, but is restored to life. The twins are burnt and pulverized, but riappear in disguise, slay the kings, subjugate their subjects, and become identified with the sun and moon. (16:9I-193.)

\section{B. - NORTH AMERICAN HERO-TALES.}

I. Western Transformer Mrths. See table on page 140.

\section{MAIDU.}

(a) Monsters kill all the people except two old men and their daughter, who marries Cloud-Man. Two sons develop out of feathers and grow up rapidily. 'The old men vainly warn them against dangers (Pittheus motive). Conqueror kills or transforms the monsters (Roc motive), reaches the house of a man who gambles for life, beats and kills him. (24:5i.)

(b) Similar adventures are narrated of Kutsem yeponi, a single hero, who develops from a bead. (24:59.)

\section{Lodge-BOY AND THROWN-AWAY CyCle.}

(First Part.) See table on page ifi.

\section{Lodge-Boy and Thrown-Away Cycle.}

(Second Part.)

(a) Shoshone. The boy's father gives them a hoop with the order not to throw it in a certain direction. The hoop rolls into a sea-monster, Water-Boy follows, is swallowed by it, but rescued by his brother. They travel homewards, are locked up in a cave, but liberated by the rain Water-Boy causes to fall. They pass a giant's bears unharmed, make snow and ice on the mountains, and finally arrive at home. Adventures in another version: killing of a gigantic bird, pursuit by a water-giant and rescue by water-spirits, passing of cactus-fields, rattlesnakes, etc. (60.)

(b) Crow. Father warns the boys against going to an old woman who boils people by drawing them into a tilted jot (pot-tilter). They disobey and kill the woman. Disregarding further warnings, they are drawn in by a sucking-monster, cut its heart, and liberate the people swallowed by it; break striking trees, kill snakes which crawl into people's rectum (rectum-snakes); dispatch a cliff-ogre; burn a man with his own firemoccasins; and kill a thunder-bird with hot stones (Roc motive). (So: 30.3.$)$

(c) Blackfoot. The boys are warned not to roll their hoop in a certain direction, but disobey. They are carried to an old woman, who tries to suffocate them, but is berself smothered. They kill snakes. One of them is enticed up a growing tree and becomes a star. The other is adopted by an old woman, wins the chief's daughter, produces a foodsupply by magic, and saves people from a famine caused by his enemy Crow. The hero is offended by his wife's disobedience, ascends to the sky, and joins his brother as a star. (9 I.)

(d) Hidatsa. Pittheus motive. The twins are swallowed by a sucking-monster, which they kill with hot stones, and overcome Pot-Tilter, fire-moccasin man, and an ogre with a magical knife. Lodge-Boy is taken to the sky by Long-Arm; his brother leaps up on an arrow, rescues him, and returns in safety. (63:63.)

(e) Gros Ventre. The boys are warned against picking up their arrows. One of them disobeys and is carried away. He magically captures buffalo, marries the chief's daughter, and is tempted by his sister-in-law (Found-in-Grass theme). (56: 70.)

(f) Arapaho. Pittheus motive. The twins slay rectum-snakes, their mother's murderer, 
Fournal of American Folk-Lore.

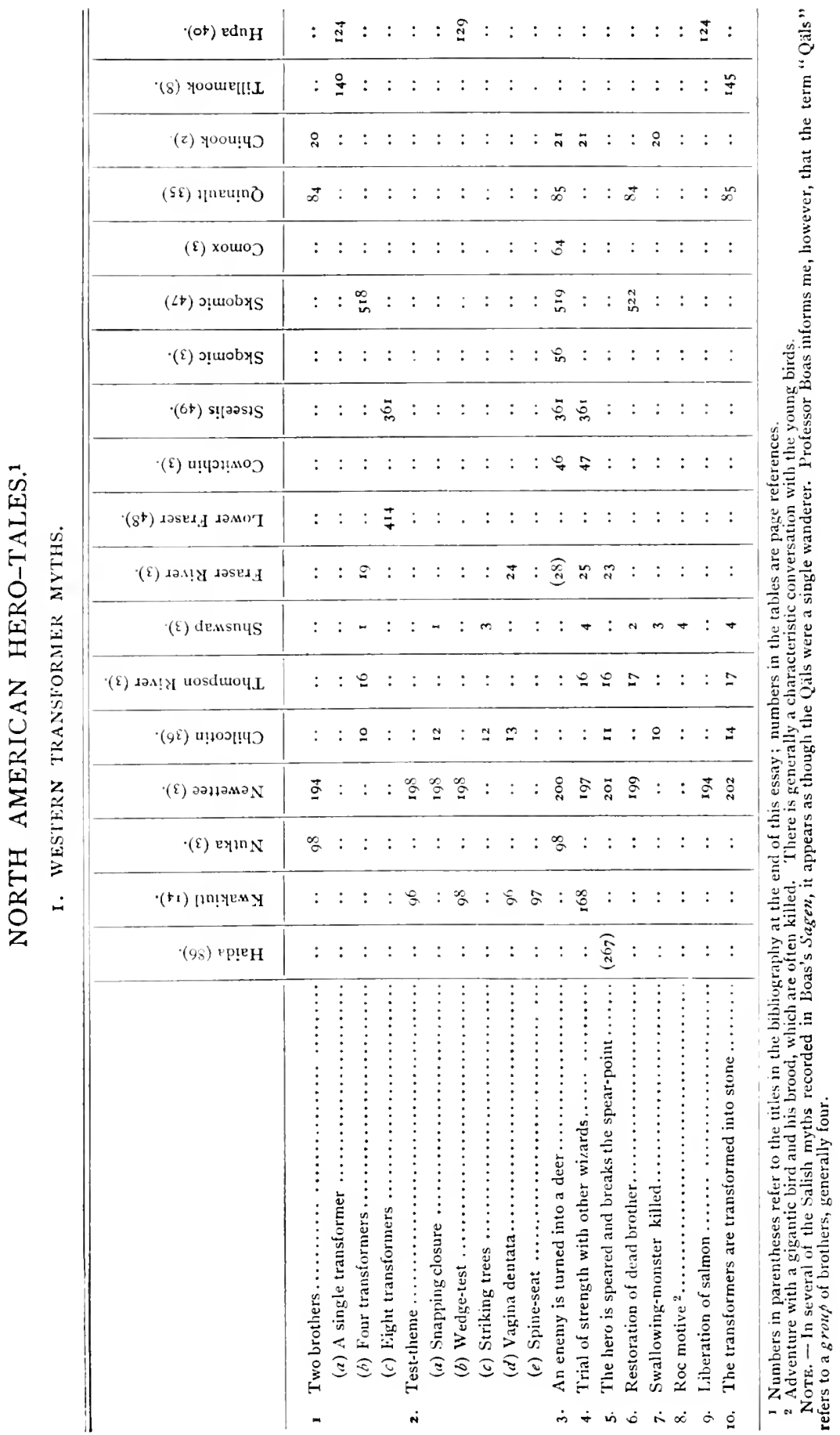


The Test-Theme in North American Mythology. $14 \mathrm{I}$

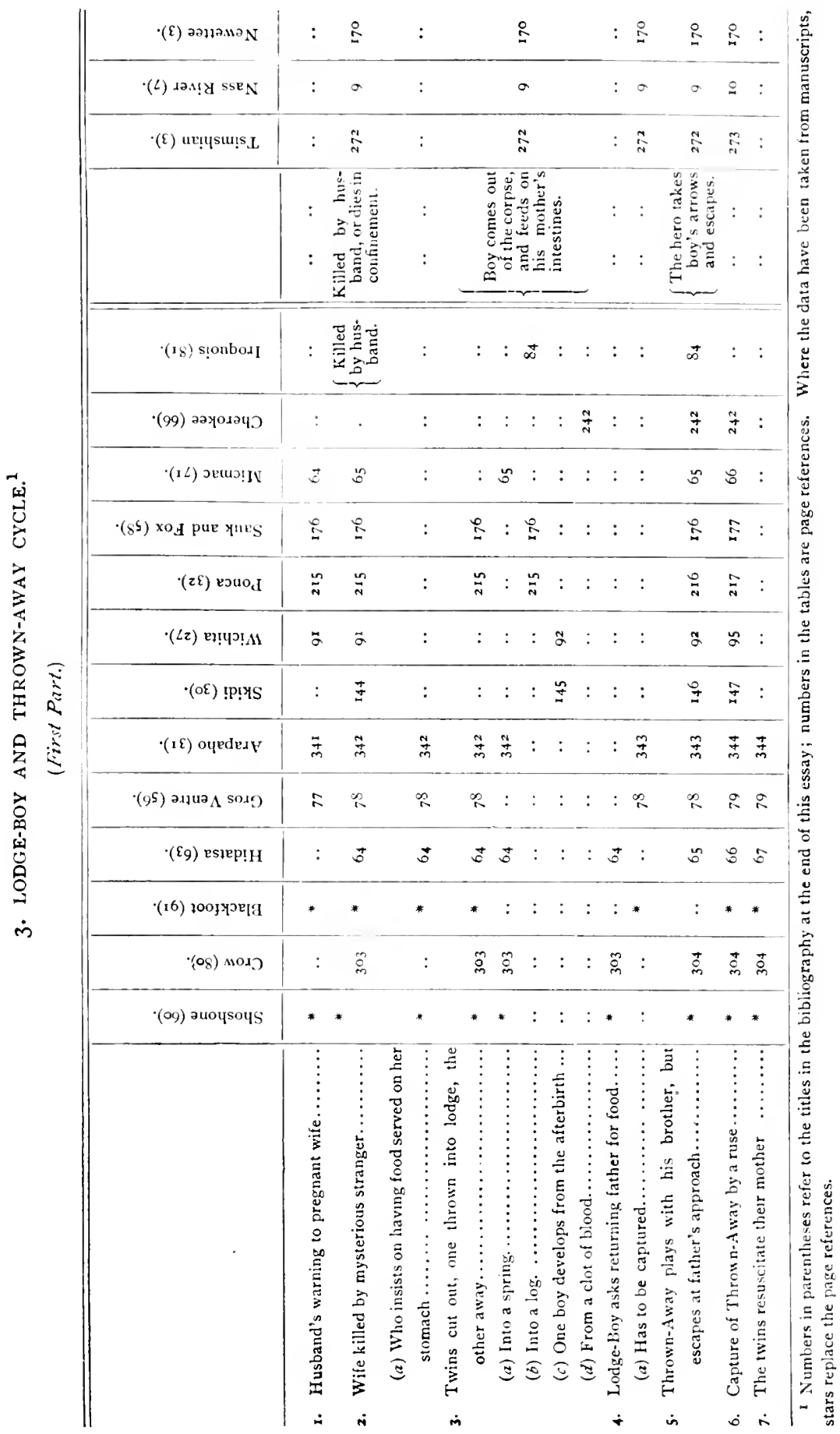


and thunder-bird. Throwing a hoop contrary to instructions, one of them is whirled away, adopted by an old woman, etc. (Found-in-Grass theme, see before). (31:3+1.)

(g) Skidi Parinee. Pittheus motive. The boys kill snakes, overcome a sucking-monster, and feign being pursued by the animal in order to frighten their father. They ride a bear for a pet, beat a witch in a race, kill dangerous buffalo and elk, and finally retire under the water. $(28: 91 ; 30: 1+3.493 .494$.

(h) Wichita. Pittheus motive. Spider-Woman tries to boil the twins, but they turn the tables on her. They visit thunder-bird (Roc motive), slay a double-faced monster, beat a man who gambles for life and death, and throw their hoop in a forbidden way. They roll into a sea-monster, which they kill. Their father, not knowing where they are, becomes a star. They find their father's track, and by means of two arrows ascend to join him. (27: 88.)

(i) Ponca. Pittheus motive. The twins cut off serpents' tails and bring them home, carry Burr-Woman to their lodge, capture thunder-birds, and fetch four-footed reptiles, - all in order to tease their father. They are in each case reproved, and return the objects brought home. (32:215.)

(j) Sauk and Fox. Pittheus motire. The twins bring snakes and burr-rock home, kill a white bull, and put up its skin to frighten their father. They take the objects back. 'The father tries to flee, fails several times, frustrated by the boys' magic, until he finally escapes. $(58: 1 ; 7$.

(k) Micmac. Spring-Boy kills Bull-Frog and releases the water hoarded by him. He paddles away with his brother and kills giants. Tested in the sweat-house, the older boy succumbs, but is resuscitated by Spring-Boy; who increases the heat so as to kill the tester. The brothers avoid poisoned food, and have a trial of strength with Glooscap. In another version, the hero is paddled away, deserted on an island by his mother-in-law while looking for eggs, but is carried home by a gull. The old woman tries to smother him with skins while he is sleeping with her daughter, but he punches holes through them and is saved. ( 7 I: 7 I, $79 ; \mathrm{cf} .72: 1+2$.

(l) Iroquois. The boys go west and kill strange beasts (fragmentary version). ( $8 \mathrm{I}: 8_{4}$.)

(m) Cherokee. The twins watch their father getting game and their mother producing corn by magic. They liberate the game, and kill their mother for a witch. The father sets wolves on them, which are conquered by the boys. They follow their wandering parent to a panther and cannibals, who do not harm them. Through the snapping entrance of sky-land they pass to heaven. where they find their parents. They are sent west, and remain there as the Thunder-Boys. $(66: 242$.)

\section{Peeblo Twin-Myths.}

(a) Sia. The twins set out to war against the skoyo (evil beings). They conquer a cliff-ogre, slay a wolf, and frighten their mother by pulling along the carcass of a slain bear as if it were alive. They are taken to an eagle's nest and kill the young birds (Roc motive). They are boiled by a witch, but cool the fire with shells, and push the woman into the fire. Mole digs a tunnel for them from which they can shoot a gigantic antelope. They transform inhospitable villagers into stone. Finally they join the Sun by stepping across the rainbow as a bridge. (84:44.)

(b) Zuñi. Rain-god's son disobeys mother's warning. He slays a bear, venomous lizards, a cliff-ogre, and an eagle that carries him to his eỵie. With Gopher's aid he shoots a gigantic ell: from the tunnel dug for him. $(23: 65,424$.)

(c) Jicarilla. Sun and Moon's sons (by the same woman) are given a hoop and warned against throwing it north. They disobey. The hoop rolls to Owl's lodge, who tries to boil the bo:s, but fails and allows them to depart. Sun-Boy is sent by his father to destroy monsters. He suffocates a sucking-frog, kills the gigantic elk with Gopher's assistance, (cf. $(x): 324 ; 38: 135)$, is carried up by an eagle (Roc motive), shoots bear in its only vulnerable spot, and destroys a rolling rock. Moon-Boy kills a great winged monster with lightning. The boys go to the western ocean, where they dwell under the sea. $(65: 201$; 74:255.) 


\section{The Test-Theme in North American Mythology.}

(d) Tusayan. The war-gods are swallowed by a monster, pierce its heart, and liberate the people found inside. They kill a bear, and frighten their grandmother by feigning flight from it. They steal thunder and lightning and cause a heavy storm; kill a monster and his wife with lightning-arrows. (90: $81-89$.)

(c) Navaho. The war-gorls kill a giant with lightning-arrows, overcome the deer with Gopher's assistance, have the characteristic adventure with the eagles (Roc motive), slay a cliff-ogre and staring-monsters, and shoot the rolling rock. $\left(61: 115^{-125}\right.$.)

\section{RABBIT CyCle.}

(a) Ponca. Rabbit is taken up by an eagle, kills the eaglets and parent birds. He captures the sun; is drawn in by a sucking-monster, and liberates the people swallowed. He kills male Winter, catches the Sun in a trap, causes menstruation, slays a giant and black bears. (32: 12, 14-15,19, 20, 22, 25,30, 34.)

(b) Menomini. Rabbit originates from a bowlful of earth dug up with a flint and then changed into blood. He is swallowed by a sucking-monster and liberates the people found in its body. He steals fire and has his skin scorched. (50: $87,126,127$.)

\section{Blood-Clot Cycle.}

\section{(First Part.)}

One man enslaves and abuses another. The victim picks up a clot of blood, which develops into a boy. Blood-Clot kills the tormentor. $(72: 102 ; 32: 48 ; 44: 29 ; 3 \mathrm{I}$ : $298 ; 56: 82 ; 28: 80$.)

\section{Blood-Clot Cycle. \\ (Second Part.)}

(a) Skidi Pawnee. Blood-Clot is adopted by an old woman as her grandson. He magically shoots buffalo, kills Burr-Woman, and disappears.

(b) Dakota. Blood-Clot meets the evil spirit Unktomi, and is transformed into a dog.

(c) Blackfoot. Blood-Clot kills a bear and a snake which steal people's food, and cuts off the sucking-monster's heart. He defeats a witch in wrestling, and hurls the cliff-ogre down the precipice. Devoured four times by a cannibal, he revives, and overcomes the monster. In another version (9 I) Blood-Clot is identified with Smoking-Star and returns to the sky at the close of his adventures.

(d) Arapaho. Blood-Clot kills cannibal women and evades their pursuing kinsmen by causing the ice to break. He conquers a cliff-ogre, kills bears, and goes to the sky. In another tale White-Owl tests him with riddles. Blood-Clot finds the correct answers and is allowed to live. $(3 \mathrm{r}: 305$.)

(e) Gros Ventre. Blood-Clot passes a falling tree without injury, having transformed himself into a feather. He leaps across a sinking bridge just in time to save himself, and liberates people from a sucking wolf's stomach. He kills Pot-Tilter by flitting by as a feather and pointing the caldron at her. He overcomes a gambling buffalo, a swinging ogre, and a man who kills people with his sharpened leg. His father-in-law tests him (see above).

\section{Star-Boy.}

\section{(First Part.)}

A woman desires marriage with a relestial being. The Star (Sun, Moon) raises her to the sky and weds her. Disobeying instructions, she discovers the sky-hole with the earth below. She plans to escape with her child, generally by a rope, but perishes in the descent; the boy reaches the earth in safety. (In several versions the woman escapes without injury, or is sent home by her husband.) (80:301;28:62;31:321;64:238; $72: 90 ; 30: 56.9 \mathrm{r}$; cf. with these such versions as $35: 107 ; 27: 298 ; 71: 160,308 ; 9: 39 ; 3: 62$.) 
IO. STAR-Boy.

(Second Part.)

(a) Crow. Star-Boy becomes a hunter, is stupefied by a rectum-snake, and never regains his former appearance (an obviously fragmentary close). (80: 301.)

(b) Skidi Pawnee. Star-Boy is adopted by an old couple. The old man (as a snake) tries to kill him, but perishes in the attempt. The foster-mother's wild beasts are conquered. The hero is attacked by a dangerous snake, but saved by his star-father. $(28: 63$.)

(c) Kitkhahki. Star-Boy is adopted by an old woman and becomes her grandson's playmate. 'The boys are warned against dangers, but disobey, kill a bear with lightning, and frighten the woman with the skin. They also slay mountain-lions and other evil animals. Star-Boy disappears, probably to join his father. (30:57.)

(d) Dakota. Star-Boy is adopted by an old couple and warned against monsters. $\mathrm{He}$ disobeys, slays two sucking-monsters, and frees the people devoured by them. In a trial of strength with the evil weather-spirit Waziya, who steals the people's food, the hero paralyzes him, and kills all his children except the youngest. ( $72: 9 \mathrm{I}$.

(e) Arapaho. Little-Star, Moon's son, kills a monster which steals food from the people, and conquers rectum-snakes. One of these crawls into his body and nearly kills him. He makes the serpent depart by causing a rain-shower, seizes the snake, and attaches it to a bow which he leaves to the people. He then becomes a star. (3I:335.)

(f) Kiozia. Sun-Boy splits into twins, who rid the world of monsters. ${ }^{1}$ At last they disappear, one becoming "medicine," the other going down a lake. (64:239.)

$(g)$ Gros lentre. Moon-Boy is warned against some girls by an old woman. He puts a flat rock under his body; the girls, as snakes, dash their heads against the stone and perish. The hero meets an old woman who engages him in a wrestling-match and tries to throw him into the fire, but conquers her. One of the girl-snakes has escaped, and crawls into his body. Moon rescues his son by causing a shower, and the boy kills the snake. $(56: 90$.

(h) Blackfoot. Morning-Star sends his wife back to the earth, warning her not to let their boy touch the ground. While she is away, the boy touches the earth. Upon her return the mother finds only a puff-ball in his place; the boy has become a fixed star. 191.)

In order to indicate the form assumed by the trial-theme outside of North America, I append a few stories from other geographical areas.

(a) Chukchee. Earth's daughter is wooed by a number of suitors. At every meal Earth strikes their hands with a knife as they reach for food. Only the hero, Attigitki, succeeds in securing food with his breath. The suitors are sent to get fuel from a tree standing in the sea; the tree-spirit shakes the trunk and drowns all except Attigitki, who gets the wood while the spirit is eating. The suitors have a trial of strength. Attigitki overcomes his rivals by means of a magic staff, and carries off the bride. (I5: 594.)

(b) Yukaghir. Raven carries off a girl. Her brother pursues him, and wins in an eating and sweat-house match. ( $15: 653$.)

(c) Koryak. Ememqut, twitted by Envious-One (or Sun), decides to win Sun-Man's (or Floating-Island's, or five-headed monster's) daughter. He is aided by his sisters (or father), passes the fiery sea in safety, and beats the sun-people in a ball-game. Sun hides his daughter, but finally surrenders her. In another version the hero is swallowed by the five-headed monster, hut runs out of its mouth and slays it. (5I: 162, 197, 323.)

(d) Japan. Oho-na-muji accompanies eighty gods who are setting out to woo a princess. The princess prefers Oho-na-muji. In revenge the gods roll a heated rock on the hero, who is, however, resuscitated by some divinities. He is subjected to the wedge-test,

1 In Shoshonean mythology a boy he ro is cut in two, each half assuming the semblance of a complete human being. $(70: 48,49$.) 


\section{The Test-Theme in North American Mythology.}

- killed, but restored by his mother He departs to the underworld to get Susanowo's advice, marries the god's daughter, and has to undergo several trials. He is locked up in the House of Snakes and the House of Centipedes and Vasps, but remains uninjured, owing to his wife's aid. Susanowo bids him fetch an arrow, and caluses a conflagration about him. The hero escapes underground, and finally reappears with the arrow. He louses Susanowo, the god falls asleep, and Oho-na-muji escapes after tying his tester's hair to the rafters of the house. $(39: 256 ; 20: 68$.)

(e) Mongolian. The princess Rogmo Goa consents to marry the man that can defeat her champion archers and wrestlers. The hero, Geser, wins. On account of his ugly appearance she sets new tests. The suitor is asked to distribute meat and liquor among ten thousand men while the princess turns her back, and to take a very large turquoise into his mouth. The hero performs both feats by magic. (77: 55 et seq.)

The prince Tshotong, jealous of his nephew Geser, awards Rogmo to the man that wins a horse-race. Aided by his divine grandmother, the hero wins. Tshotong then promises the princess to the hunter that can kill a wild bull, to the man that will kill ten thousand bulls, to the captor of the bird Garuda's tail-feathers. Geser defeats his competitors in every trial. (77:67.)

Geser offends the Emperor of China, and is thrown into a snake-pit. He spurts a fluid on the serpents and kills them. He is then successively thrown into the caves of ants, lice, wasps, and wild beasts, but eonquers them all. When shut up in a dark cave, he catches the sun and moon. Cast into the sea, he dries it up, quenches the fire to which he is exposed, and by his magic baffles the prince's warriors. The Emperor is finally obliged to give up his daughter to Geser. (77: 104.)

(f) Finland. Wäinamöinen wooes the maiden of Pohja. She bids him split a horse's hair with an unsharpened knife; to make a knot with an egg; to peal off the outer part of a stone; to cut poles of ice without breaking off the slightest splinter; to build a boat from the splints of a distaff. He succeeds in every trial but the last, in which he is wounded. He returns to his home.

The mistress of Pohja refuses her daughter to Lemminkäinen unless he should capture the reindeer of Hiisi. After an unsuccessful venture, he succeeds with the aid of the forest deities. He is next required to tame Hiisi's colt. Though successful, he is put to the task of shooting the swan of a sacred river. In this undertaking he perishes.

Ilmarinen, another suitor, is asked to plough a field of vipers, to capture and tame a wild bear and wolf, and to conquer a gigantic pike. Counselled by the girl, he succeeds, and wins the maiden. ( $68: 9 S$, I $_{75}, 284=$ Runes 8, I $_{3}, \mathbf{1}_{4}, 18$.)

(g) German. A soldier, accompanied by five servants with wonderful powers, wooes the king's daughter, who tests suitors in a race. One of the hero's companions runs for him, outstrips the girl, and lies down to rest before returning to the goal. The girl overtakes him, but as she approaches, a far-sighted member of the party awakes the sleeping runner, who wins the race for his master. The king invites the victor to a feast in a - closed chamber heated from below. One of the friends dons his hat, which immediately cools the room, freezing the food. The king then offers to redeem his daughter with as much gold as can be carried away by one of the servants. The strongest is dispatched, and carrics off the whole treasury, while the lifth servant repels the pursuing army by blowing them into the air. (43:246-250.) A somewhat similar tale is narrated under the title "Die sechs Diener." (43: 43 I et seq.)

(g) Samoa. A deity promises his daughter to Siati, provided the youth overcomes him in a singing-contest. The youth wins, and marries the girl, who warns him against her father. The god asks the hero to build a house for him in a day, or die. His wife performs the task for him. He is then obliged to fight a $\mathrm{dog}$ and to find a ring lost by his father-in-law. He succeds in both undertakings, and escapes in a magic flight, in which the pursuer perishes. (S8: 102-104.)

The pcople of Samoa ascend to the sky, Tangaloa's people plot to slay them. The kava set before the guests is poisoned, but does not hurt them. They have a trial as to who could sit in the rain longer, and the visitors win. Next, there is a floating-match VOL. XXI. - NOS. $8 I-\$ 2$. 
down a cataract; one of the Samoans plants his feet against a rock and casts his followers in safety to the land, while their opponents are killed. Food is served to the guests, and the hosts plan to kill them while eating, but the Samoans eat up both food and baskets, so that the amazed subjects of Tangaloa are afraid to make an attack. At last there is a club-game. The Samoans win, and depart with gifts of fine mats. (88: 249-251.)

\section{ALTHORITIES QLOTED}

I. Boas, Franz. The Central Eskimo. (Sixth Annual Report of the Bureau of Ethnology; pp. 399-699. Washington, IS8S.)

2. - Chinook Texts. (Bulletin 20, Bureau of American Ethnology. Washington, I 894.)

3. - Indianische Sagen von der Nord-Pacifischen Küste Amerikas. Berlin, I895.

4. - The Mythology of the Bella Coola Indians. (Publications of the Jesup North Pacific Expedition, vol. i, pp. 25-127. Leiden, 1900.)

5. - The Eskimo of Baffin Land and Hudson Bay. (Bulletin of the American Museum of Natural History, vol. xv. New York, rgor.)

6. - Kathlamet Texts. (Bulletin 26, Bureau of American Ethnology. Washington, I $90 \mathrm{I}$.)

7. - Tsimshian Texts. (Bulletin 27, Bureau of American Ethnology. Washington, 1902.)

8. - Traditions of the Tillamook Indians. (Journal of American Folk-Lore, vol. xi, pp. $23-38,133-150$.)

9. - Traditions of the Tsetsaut. (Journal of American Folk-Lore, vol. ix, pp. 257268 ; vol. $\mathrm{x}, \mathrm{pp} .35^{-48}$.)

ro. - - The Folk-Lore of the Eskimo. (Journal of American Folk-Lore, vol xrii, pp. $I-13$.

II. - The Social Organization and the Secret Societies of the Krakiutl Indians. (Report U. S. Nat. Mus. I 895 , pp. 3I I-737. Washington, I $89 ;$.)

12. - Einige Sagen der Kootenay. (Verhandl. d. Berl. Ges. f. Anth., Ethnol. u. Urgesch. I 891, pp. I61-i $; 2$.)

13. - Northern Elements in the Mythology of the Navaho. (American Anthropologist, 1897 , pp. $37 \mathrm{i}-376$.)

I4. Boas and Hunt. Kwakiutl Texts. (Publications of the Jesup North Pacific Expedition, vol. iii. Leiden, 1902.)

15. Bogoras, Waldemar. The Folk-Lore of Northeastern Asia. (American Anthropologist, N. S., 1902, pp. 5; $-68_{3}$.)

16. Brasseur de Bourbourg. Popol Vuh, Le Livre Sacré et les Mrthes de L'Antiquité Américaine arec les Lirres Heroiques et Historiques des Quichés Paris, I861.

17. Brinton, Daniel G. The Myths of the New World. Philadelphia, r 868.

18. Chamberlain, A. F. Tales of the Mississaguas. (Journal of American Folk-Lore, vol. iii. pp. I $49-154$.)

19. Chamberlain, Basil Hall. Ainu Folk-Tales. London, i 888.

20. — Kojiki. (Transactions of the Asiatic Society. of Japan, vol. $x$, Supplement, I $88_{3}$.)

2I. Codrington, R. H. The Melanesians; Studies in their Anthropology and Folk-Lore. Oxford, isgr.

22. Curtin, Jeremiah. Creation Myths of Primitive America. Boston, 1898 .

23. Cushing, Frank Hamilton. Zuñi Folk-Tales. New York, 1901.

24. Dixon, Roland B. Maidu Myths. (Bull. Am. Mus. Nat. Hist. vol. xrii, part ii, pp. 33-118. New York, I902.)

25. Some Coyote Stories from the Maidu Indians of California. (Journ. of Am. Folk-Lore, vol. xiii, pp. 267-270.)

26. Dorscy, George A. Traditions of the Osage. (Field Columbian Museum, Pub. 8S, vol. vii, no. I, Chicago, 1904.) 


\section{The Test-Theme in North American Mythology.}

27. Dorsey, George A. The Mythology' of the Wichita. Washington, I90.4.

28. - Traditions of the Skidi Pawnee. Boston and New York, 1904.

29. - Traditions of the Arikara. Waslington, I904.

30. - The Pawnee Mythology. (Part r.) Washington, 1906.

31. Dorsey and Kroeber. Traditions of the Arapaho. (Field Columbian Museum Pub. 8I, vol. v. Chicago, 1903.)

32. Dorsey, James O. The Cegiha Language. (Contributions to North American Ethnology, vol. vi, I 890.)

33. Ehrenreich, Paul. Die Mythen und Legenden der südamerikanischen Urvölker und ihre Beziehungen zu denen Nordamerikas und der alten Welt. Berlin, 1905.

34. - Götter und Heilbringer. (Zeitschrift für Ethnologie, vol. xxxviii, 1906, pp. 5366ro.)

35. Farrand, Livingston. Traditions of the Quinault Indians. (Publications af the Jesup North Pacific Expedition, vol. ii, pt. iii, Pp. 77-132. Leiden, 1902.)

36. - Traditions of the Chileotin Indians. (Ibid. pt. i, pp. I-54.)

37. Fewkes, J. Walter. The Snake Ceremonial at Walpi. (A Journal of American Ethnology and Archæology, vol. iv, I 894.)

38. The Destruction of the Tusayan Monsters. (Journ. of Am. Folk-Lore, vol. viii, pp. $132-137$.)

39. Florenz, Karl. Japanische Mỵthologie. (Nihongi, "Zeitalter der Götter." Nebst Ergänzungen aus anderen alten Quellenwerken. Tokyo, I9or.)

40. Goddard, Plinỵ E. Hupa Texts. (University of California Publications, Am. Arch. and Eth. vol. i, no. 2, I904.)

4I. Golder, F. A. Tales from Kodiak Island. (Journ. of Am. Folk-Lore, vol. xvi, pp. I6-3I.

42. Grey, Sir George. Polynesian Mythology and Ancient Traditional History of the New Zealanders. London, George Routledge \& Sons. No date.

43. Grimm, Brüder. Kinder und Hausmärchen, 32. Auflage besorgt von Reinhold Steig. Stuttgart und Berlin, I9o6.

44. Grinnell, George B. Blackfoot Lodge Tales. New York, 1903.

45. Hahn, J. G. von. Sagwissenchaftliche Studien. Jena, 1876.

46. Hill-Tout, C. Notes on the Ntlakapamuq of British Columbia. (Report of the British Association for the Advancement of Science, 1899, pp. 500-584.)

47. - Notes on the Skqomic of British Columbia. (Ibid. I900.)

pp. $47^{2-549 .)}$

48. - Ethnological Studies of the Mainland Halkomelem. (Ibid. I902, pp. 335-449.)

49. - Ethnological Report of the Stseelis and Skaulits Tribes. (Journal of the Anthropological Institute, vol. xxxiv, I904, pp. $31 \mathrm{I}-376$.)

50. Hoffmann, Walter. The Menomini Indians. (Fourteenth Annual Report of the Bureau of Ethnology, pt. i, pp. 3-328. Washington, 1896.)

51. Jochelson, The Koryak. Religion and Myths. (Jesup North Pacific Expedition, vol. vi, pt. I. Leiden, 1905.)

52. Krause, Aurel. Die Tlinkit-Indianer. Jena, 1885.

53. Krauss, Friedrich S. Anthropophyteia. Band r. Leipzig, 1904.

54. Kroeber, Alfred. Cheyenne Tales. (Journ. of Am. Folk-Lore, vol. xiii, pp. 16r-190.)

55. - Ute Tales. (Journ. of Am. Folk-Lore, vol. xiv, pp. 252-285.)

56. - Gros Ventre Myths and Tales. (Anthropological Papers of the American Museum of Natural History, vol. i, pp. 55-139.)

57. Lang, Andrew. Custom and Myth. London, 1885.

58. Lasley, Mary. Sac and Fox Tales. (Journ. of Am. Folk-Lore, vol. xv, pp. 170I 78.)

59. Laufer, Berthold. Preliminary Notes on Explorations among the Amoor Tribes. (American Anthropologist, N. S. 1900, pp. 297-338.)

60. Lowie, Robert H. Shoshone Myths. MS.

6r. Matthew's, Washington. Navaho Legends. Boston and New York, I 897. 
62. Matthews, Washington. The Origin of the Ltes. A Navajo Myth. (American Antiquarian and Oriental Journal, vol. vii ( 1885 ), pp. $27 \mathrm{I}-27+$.)

63. - Ethnography and Philology of the Hidatsa Indians. (U. S. Geolog. and Geograph. Survey. Miscellaneous Publications, no. 7. Washington, 1877.)

64. Mooney, James. The Calendar History of the Kiowa. (Serenteenth Annual Report of the Bureau of Ethnology, pp. 129-468. Washington, 1898.)

65. - The Jicarilla Genesis. (American Anthropologist, I898, pp. 197-209.)

66. - Myths of the Cherokee. (Nineteenth Annual Report of the Bureau of American Ethnology, pt. I. Washington, 1900.)

67. Morice, Rev. Father. Three Carrier Myths. (Transactions of the Canadian Institute, vol. v (1898), pp. 1-36.)

68. Paul, Hermann. Kalewala, das Volksepos der Finnen. Helsingfors, i 885.

69. Petitot, Émile. Traditions Indiennes du Canada Nord-Ouest. Paris, I 886.

70. Powell, John W. A Sketch of the Mythology of the North American Indians. (First Annual Report of the Bureau of Ethnology, pp. $7_{7-56}$. Washington, 188I.)

71. Rand, Silas T. Legends of the Micmacs. New York and London, I894.

72. Riggs, Stephen R. Dakota Grammar, Texts, and Ethnography. (Contributions to North American Ethnology, vol. ix. Mashington, IS93.)

73. Russell, Frank. Explorations in the Far North. I 898.

74. - Myths of the Jicarilla Apache. (Journ. of Am. Folk-Lore, vol. xi.)

75. St. Clair, H. H. Coos Texts. MS.

76. Sapir, Edward. Wishram Texts. (Publications of the American Ethnological Society, vol. ii.)

77. Schmidt, I. J. Die Thaten Bogda Gesser Chan's, des Vertilgers der Wurzel der zehn Übel in den zehn Gegenden. Eine ostasiatische Heldensage, aus dem Mongolischen übersetzt. St. Petersburg, I 839 .

78. Schoolcraft, Henry R. The Myth of Hiawatha. Philadelphia, 1856.

79. Seler, Ed. Einiges über die natürlichen Grundlagen mexikanischer Mythen. (Zeitschrift f. Ethn. 1907, pp. I-4r.)

8o. Simms, S. C. Traditions of the Crows. (Field Columbian Mus. Pub. 85, vol. ii. Chicago, 1903 .)

8I. Snrith, Erminnie A. Myths of the Iroquois. (Second Annual Report of the Bureau of Ethnology, pp. 47-1 6 . Washington, 1 $88_{3}$.)

82. Speck, Frank. Yuchi Myths. MS.

83. Steinen, Karl von den. Unter den Naturvölkern Zentral-Brasiliens. Berlin, 1893 .

8. Stevenson, Matilda C. The Sia. (Eleventh Annual Report of the Bureau of Ethnology, pp. $3^{-1} 57$. Washington, I 894 .)

85. - The Zuñi Indians. (Twenty-third Annual Report of the Bureau of American Ethnology: Washington, 1904.)

86. Swanton, John R. Haida Texts and Myths. (Bureau of American Ethnology, Bulletin 29. Washington, I905.)

87. Teit, James. Traditions of the Thompson River Indians of British Columbia. Boston and New York, 1898 .

88. Turner, George. Samoa, a Hundred Years Ago and Long Before. London, 1884.

89. - Nineteen Years in Polynesia. London, 1864.

9o. Voth, H. R. The Traditions of the Hopi. (Field Columbian Mus. vol. viii. Chicago, 1905.)

91. Wissler, Clark. Blackfoot Myths. MS.

92. - Some Dakota Myths. (Journ. of Am. Folk-Lore, vol. xx, pp. I21-I31, 195-206.)

93. Wundt. Wilhelm. Völkerpsychologie. Zweiter Band: Mythus und Religion, Erster Teil. Leipzig, I 905 .

Columbia Uxiversity, New York City. 


\section{EDUCATIONAL ATTENDANCE}

1889-1896. Attended the public schools of Vienna and New York.

1896-1901 Attended the College of the City of New York.

\section{1}

A. B. at the College of the City of New York.

1901-1904 Taught in the public school system.

I904-1907 Took courses at Columbia University in the departments of ethnology and psychology. 


